\title{
The Highest Peaks of the Mountains: Comparing the Use of GNSS, LiDAR Point Clouds, DTMs, Databases, Maps, and Historical Sources
}

\author{
Stanisław Szombara ${ }^{1, *(\mathbb{D})}$, Marta Róg ${ }^{1} \mathbb{D}$, Krystian Kozioł $^{1}\left(\mathbb{D}\right.$, Kamil Maciuk ${ }^{1,2} \mathbb{D}$, Bogdan Skorupa ${ }^{1}$ (D), \\ Jacek Kudrys ${ }^{1,2} \mathbb{D}$, Tomáš Lepeška ${ }^{3} \mathbb{D}$ and Michal Apollo ${ }^{2,4,5}$ (D)
}

1 Department of Integrated Geodesy and Cartography, AGH University of Science and Technology, 30-059 Krakow, Poland; martarog@agh.edu.pl (M.R.); krystian.koziol@agh.edu.pl (K.K.); maciuk@agh.edu.pl (K.M.); bskorupa@agh.edu.pl (B.S.); jkudrys@agh.edu.pl (J.K.)

2 Joint International Tourism College, Hainan University-Arizona State University, Haikou 570228, China; michal.apollo@up.krakow.pl

3 Department of Applied Ecology, Faculty of Ecology and Environmental Sciences, Technical University in Zvolen, T.G. Masaryka 24, SK-960 01 Zvolen, Slovakia; tomaslepeska@yahoo.com

4 Department of Tourism and Regional Studies, Institute of Geography, Pedagogical University of Krakow, 30-084 Krakow, Poland

5 Center for Tourism Research, Wakayama University, Wakayama 640-8510, Japan

* Correspondence: szombara@agh.edu.pl

check for updates

Citation: Szombara, S.; Róg, M.; Kozioł, K.; Maciuk, K.; Skorupa, B.; Kudrys, J.; Lepeška, T.; Apollo, M. The Highest Peaks of the Mountains: Comparing the Use of GNSS, LiDAR Point Clouds, DTMs, Databases, Maps, and Historical Sources. Energies 2021, 14, 5731. https:// doi.org/10.3390/en14185731

Academic Editor: Benedetto Nastasi

Received: 30 July 2021

Accepted: 8 September 2021

Published: 11 September 2021

Publisher's Note: MDPI stays neutral with regard to jurisdictional claims in published maps and institutional affiliations.

Copyright: (c) 2021 by the authors. Licensee MDPI, Basel, Switzerland. This article is an open access article distributed under the terms and conditions of the Creative Commons Attribution (CC BY) license (https:/ / creativecommons.org/licenses/by/ $4.0 /)$.

\begin{abstract}
Advances in remote data acquisition techniques have contributed to the flooding of society with spatial data sets and information. Widely available spatial data sets, including digital terrain models (DTMs) from aerial laser scanning (ALS) data, are finding more and more new applications. The article analyses and compares the heights of the 14 highest peaks of the Polish Carpathians derived from different data sources. Global navigation satellite system (GNSS) geodetic measurements were used as reference. The comparison primarily involves ALS data, and selected peaks' GNSS measurements carried out with Xiaomi Mi 8 smartphones were also compared. Recorded raw smartphone GNSS measurements were used for calculations in post-processing mode. Other data sources were, among others, global and local databases and models and topographic maps (modern and old). The article presents an in-depth comparison of Polish and Slovak point clouds for two peaks. The results indicate the possible use of large-area laser scanning in determining the maximum heights of mountain peaks and the need to use geodetic GNSS measurements for selected peaks. For the Polish peak of Rysy, the incorrect classification of point clouds causes its height to be overestimated. The conclusions presented in the article can be used in the dissemination of knowledge and to improve positioning methods.
\end{abstract}

Keywords: GNSS; LiDAR; DTM; data quality; mountains

\section{Introduction}

Mountains have always fascinated mankind. Since ancient times, researchers have tried to measure the heights of peaks as accurately as possible [1]. Modern measuring techniques allow for quick, direct, and remote measurements of heights in mountainous areas. The currently used direct methods include precise trigonometric levelling [2], global navigation satellite system (GNSS) [3], and levelling [4]. Remote measurement methods used nowadays include LiDAR [5-7], radar [8-10], photogrammetric methods [11,12], and thermography [13]. The exact height of mountain peak is of interest to researchers and the public around the world. Information regarding the height of the highest peaks of mountain ranges or regions is particularly important. Researchers are, for example, interested in the influence of glaciers on the height of mountain ranges all over the world [14], or in the height of Mt. Everest $[15,16]$. The interest in measuring heights of the highest mountains 
of given ranges is also not weakening at the regional level [17-19]. This also applies to the heights of groups of peaks belonging to the highest peaks (crowns) of a country. In addition to the measurement data, analyses of maps and literature on mountain areas are particularly interesting. Such sources provide not only information about heights, but also about land cover [20] and geological ground [21].

Large-scale aerial laser scanning (ALS) is today the most common technique used in verifying the heights of mountain peaks. ALS in mountainous areas is also used in geomorphology [22], forestry [23], and the detection of glacier changes [24]. The accuracy of determining height and relief is influenced by many factors, such as factors related to errors in measurement instruments, measurement parameters, algorithms, and the variety of the terrain surface $[13,25]$. It can also be affected by point cloud density and the spatial distribution of points on the surface [26]. The algorithms used to create digital terrain models (DTMs) in forest areas have a particularly large impact on the accuracy of height determination [27-29].

Information about the coordinates, including the height of terrain objects, is important for professional service robots including field robots and personal service robots [30,31]. Robots for outdoor applications are equipped with a navigation system that uses GNSS measurements. The navigation system along with the supporting geographic information system (GIS) helps service robots, among others, in tasks related to landscape management $[32,33]$. Autonomous robots can be equipped with systems that allow them to operate in a completely unknown environment or in terrain with previously known altitudes and morphology [30,34]. For robots that mimic human movement, the height of field objects is an important piece of information [35]. External navigation for robots based on global and local DTMs is being developed along with the development of GIS technology and robots [36]. It should be noted that in most applications for service robots, it is not the absolute height that is important, but the height difference (relative height). However, information about the highest point locally—the highest point of a mountain peak-is considered important. The development of AI technology and robots also affects the tourism industry [37]. Devices assisting people are becoming more and more popular, so far as indoor service robots [38]. In mountainous areas, unmanned aerial vehicles (UAVs) are currently used (apart from the obvious applications for data acquisition) for tasks related to agriculture [39] or SAR (search and rescue) missions [40]. The algorithms used in UAVs are currently being intensively developed to make SAR missions of lost tourists more effective [41]. The correct determination of height and location of the highest points of mountain peaks is especially important in the areas with little tourist traffic. These points may be prioritized in SAR missions [42].

Mountains are among the most popular tourist destinations. Tourists climb them for various reasons [43,44]; however, when choosing the destination, they generally focus on summits that have a certain type of subjective popularity or objective significance, such as the highest or the most prominent mountains in a region. Recent studies showed that height mistakes can have a serious influence on tourism from both local and global perspective [45]. Overall, an activity in which hikers, climbers, and mountaineers attempt to reach a collection of summits is known as 'summit bagging' [46]. This activity has been observed around the world $[47,48]$. In Poland, the quest of reaching all peaks from the list is called 'The Highest Points of the Polish Mountains' (pol. Korona Gór Polski) and is becoming increasingly popular. However, based on the data from [49], due to serious cartographic misinterpretations, this list has serious errors, not only in terms of altitude, but also in terms of location (wrong indication). A similar implication for tourism can be observed in the case of less prominent mountain ranges. According to the GNSS research conducted by [49], as many as five mountain peaks in the Sudetes lose the title of the highest summit in the range. Other studies highlighted the inaccuracies in lists of this kind on the example of the Europe Country High Points [45].

Apollo et al. [45] emphasised that lower and less-known summits that are popular with tourists are in urgent need of re-evaluation, especially where altitude differences can 
measure up to several metres. As a result of inaccurate altitude determination, tourists are misled into climbing summits that are not the highest. Overall, this has significant implications for the management and marketing of destinations when a mountain's popularity is based upon it being the highest.

Starting from Android 7.0, the users of smartphones equipped with a satellite navigation module have access to raw code and phase GNSS measurements [50]. This enables the elaboration of recorded GNSS observations in a post-processing mode [51,52]. Since then, there have been numerous publications describing research on the accuracy and reliability of positioning with the use of mobile devices [53-57]. This paper describes measurements carried out in real field conditions, without the possibility of selecting measurement stations. This gives a view of the real possibilities of using smartphones as measuring instruments. The accuracy of measurements of this type corresponds to that of field robots navigation devices.

Conceptually, this paper goes halfway between a specific field study and a critical review of existing sources of mountain altitudes. It is trying to provoke a useful discussion about the need to remeasure peak altitudes. This comprehensive approach is quite unique, as previous studies focused on area studies [58], selected data sources [12,59], and analyses of a single mountain range or peak [33]. The above-mentioned papers along with other articles published in specialist journals [29] mention the necessity to undertake comprehensive studies. The present authors are aware that a different level of data generalisation often makes it impossible to compare sources for entire mountain areas, but it is possible for single and well identifiable terrain objects, such as the highest mountain peaks. Thus, it is a rare approach to include open databases, book resources, or old maps in analyses and comparisons. Such an approach gives a wide context for the occurrence of mountain peak height data in the social information space. The article presents the results of a study on the verification of heights of 14 mountain peaks using the following data sources:

- Large-area laser scanning-point clouds, digital terrain models (DTMs),

- Direct GNSS measurements-performed with surveying equipment and smartphones,

- Modern national databases, global DEMs, and other databases,

- Topographic maps and tourist guidebooks,

- Old maps-occurring as the first source of information on the height of peaks.

The possibility of using point clouds in determining heights of the highest peaks of the Tatra Mountains have been described in detail. For this purpose, we used Polish and Slovak datasets transformed to a uniform altitude system. The research presented in this article is a continuation of the team's research from 2019, 2020, and 2021 [49].

As a comprehensive case study, this paper consists of four sections and the Introduction. In Section 2, Materials and Methods, we describe the data sets used, the processing methods, and the study area. Section 3 focuses on the results obtained from various sources. The analyses and results obtained for point clouds and derived DEM models are described in detail. Section 4 discusses the results in the light of current knowledge. Section 5 presents conclusions and the significance of the obtained results. The paper also contains two appendices with a table summarising the height values derived from each source and height difference graphs.

\section{Materials and Methods}

The article discusses 33 sources of data on mountain heights. This section describes the sources used in the research. Measurement results and values derived from maps, literature, and databases are presented in the table in Appendix A. All data sources, if possible, were converted to the KRON86-NH elevation system, or data stored in this system were downloaded. GNSS measurements, Polish, and Slovak point clouds and DTM models based on them are consistent. Other data, if possible, were converted to the sea level in Kronstadt to which the KRON86-NH system refers. For example, on all used topographic maps, the heights of mountains were given in the Kronstadt system. 


\subsection{GNSS—Geodetic Measurements}

The measurement methodology was the RTK (Real Time Kinematic) technique, as it is a fast and accurate method. When it was impossible to get a precise (fix) solution, a static measurement session was performed in field.

RTK mode was based on three independent measurements (disconnection of the receiver and reconnection with the stream of corrections) and 30-s fix solutions using corrections from the ASG-EUPOS network (asg-eupos.pl). When it was not possible to get an RTK fix solution (unfavourable distribution of reference stations or no GSM signal), a 1-h static session with a 1-s interval was performed. The obtained observations were post-processed based on the final IGS orbits in the GNSS Solutions software, using the national quasi-geoid model (PL-Geoid2011) to obtain normal heights (in the KRON86-NH system). In the case of RTK measurements, normal heights (using the same quasi-geoid model) were obtained directly in the field. The obtained heights were affected by an error of $5-10 \mathrm{~cm}$. The measurement results are presented in Appendix A in column (1).

\subsection{Polish ISOK}

Point clouds from airborne laser scanning for the territory of Poland were obtained as part of the ISOK project (IT System for the Protection of the Country against Extraordinary Hazards, pol. Informatyczny System Osłony Kraju przed nadzwyczajnymi zagrożeniami) [60]. The assumptions of the project were related to the risk of natural disasters, mainly floods, but since 2014, data have covered the entire country, not only the areas at risk. The following accuracies for point clouds were assumed: height accuracy (mean error) of the ALS point clouds after alignment: $\mathrm{mh} \leq 0.15 \mathrm{~m}$ (Standard I) and $\mathrm{mh} \leq 0.10 \mathrm{~m}$ (Standard II). The horizontal accuracy is $\mathrm{mp} \leq 0.50 \mathrm{~m}$ and $\mathrm{mp} \leq 0.40 \mathrm{~m}$, respectively. The permissible mean error values for standard I, in which all the measurements used in the article were conducted, are of the height accuracy $\mathrm{mh} \leq 0.22 \mathrm{~m}$ and of the horizontal accuracy $\mathrm{mp} \leq 0.75 \mathrm{~m}$. Point clouds in Standard II were acquired mainly for large-city areas. The decision to cover the entire country with LiDAR measurements was of great practical and scientific importance. Point clouds and their derivatives are used in many industries and fields of science. The Head Office of Geodesy and Cartography, which is one of the institutions supervising the project, also provides DTM and DSM (digital surface model) with a resolution of $1 \mathrm{~m}$. The RMSE (root-mean-square error) of DTM for natural surfaces without vegetation is estimated at $0.1 \mathrm{~m}$. For areas covered with vegetation, RMSE is app. $0.2 \mathrm{~m}$, and in the case of dense vegetation, RMSE can reach $0.5 \mathrm{~m}$. The heights from this data source are shown in Appendix A in columns (2) and (3).

\subsection{Slovak LiDAR—Data Characteristics}

Slovak LiDAR data are made available to the public by Geodesy, Cartography and Cadastre Authority of the Slovak Republic (Úrad geodézie, kartografie a katastra Slovenskej republiky - ÚGKK SR) and can be accessed and downloaded for free via Slovak Geoportal [61]. The territory of Slovakia is divided into 42 regions which are gradually being covered by ALS. The ALS data are then classified and processed to DMR 5.0-DTM, and, optionally, DMP 1.0—DSM, both with $1 \times 1 \mathrm{~m}$ grid cell size. There are several criteria which need to be met by ALS products and are subject to control, e.g., point cloud density $\min .5 \mathrm{pts} / \mathrm{m}^{2}$, absolute vertical accuracy $\mathrm{mh} \leq 0.15 \mathrm{~m}$, absolute horizontal accuracy $\mathrm{mp} \leq 0.30 \mathrm{~m}$. Furthermore, in the Ground class there can be no more than $0.5 \%$ of misclassified points per $1 \mathrm{~km}^{2}$ [62]. Data downloaded directly from the Slovak Geoportal are in S-JTSK (JTSK03) coordinate system, with heights in Baltic Vertical Datum (Bpv). The heights from this data source are shown in Appendix A in columns (4) and (5).

One region of accessible data is the area of the Tatra mountains (no. 26), with two peaks included in the present analysis-Rysy in the High Tatras and Starorobociański Wierch in the Western Tatras. The ALS flights were conducted there between 7 June 2018 and 12 September 2018 and covered the area of $959 \mathrm{~km}^{2}$ in total. The accuracy of data is 
$0.04 \mathrm{~m}$ vertically and $0.17 \mathrm{~m}$ horizontally, and the average density of last-return points is $30 \mathrm{pts} / \mathrm{m}^{2}[63]$.

\subsection{Slovak LiDAR—Data Processing}

In the beginning, it was necessary to download ALS datasets that covered the peaks of our interest. In the case of Rysy, these were four point clouds and, in the case of Starorobociański Wierch, there were two. The analyses were conducted in QGIS 3.10.3 with the enabled LAStools plugin. At first, the point clouds were clipped to extents created around the summits. Then, they were converted from .las to .txt format, with preserved information about classification. The datasets were loaded to QGIS as CSV files with known geometry and assigned S-JTSK coordinate system. Future comparison of Slovak and Polish data required height transformation from Bpv to KRON86-NH. This was a three-stage procedure. Two .gtx raster files provided by ÚGKK SR [64], representing the differences in height between Bpv and ETRS 89, and ETRS 89 and EVRF2007 were used. The value from the first raster was added to the height in Bpv and then the value from the second raster was subtracted from the previous output. The last stage of this operation was transforming the heights to the final system-KRON86-NH. This was done by subtracting an appropriate difference value, in accordance with the data presented on the website of the Polish Geoportal (Height difference model) [65]. Next, the point clouds were transformed into PL-1992 coordinate system. The data sets prepared in such a way were then ready for further analyses and comparisons.

\subsection{Smartphones GNSS Measurements}

At selected peaks, GNSS measurements were carried out using the Xiaomi Mi 8 smartphone, equipped with a Broadcom BCM47755 chipset. The measurement results are presented in Appendix A, in column (6). This receiver enables code and phase measurements of GPS, GLONASS, Galileo, and Beidou satellite systems. The observations were recorded in sessions of several tens of minutes length, with a one-second recording interval. The measurement data were stored in the smartphone's memory using the Geo++ RINEX Logger program [66] in the RINEX-Receiver Independent Exchange Format. The observations were post-processed using the RTKLib software [67]. The peak heights were determined based on the static sessions calculations in relation to the closest permanent stations of the EPN—EUREF GNSS Permanent Network. The calculated ellipsoidal heights were transformed to the KRON86_NH reference system, using the height anomaly from the PL-geoid-2011 quasi-geoid model.

\subsection{Global DEMs, Databases, and Internet Sources}

This group of sources includes both global and local data sources. One of the global data sources is SRTM [68]. The nearly global elevation model is derived from a satellite mission using a radar interferometer. Depending on the latitude and terrain, the error in determining the height may vary from a few to several metres. Another global DEM model analysed in this paper is the Copernicus DEM 30m (GLO_30) [69]. The model is provided in Horizontal Coordinate Reference System WGS84-G1150 and Vertical Coordinate Reference System EGM2008. The Absolute Vertical Accuracy for this model does not exceed $4 \mathrm{~m}$ (at $90 \%$ linear error). The model is made available by the European Space Agency. A more accurate DEM model $(10 \mathrm{~m})$ is also provided by ESA (EEA-10), but as it is available commercially or to selected user groups only, it was not used in the analyses. Due to its smaller terrain pixel, it can be assumed that the height differences would be smaller for it, despite the same Absolute Vertical Accuracy reported by the provider. In order to be able to compare the height values the data have been referenced to the sea level in Kronstadt. One of the data sources was also the height model used in the Google Earth application. The SRTM model and heights in Google Earth have the same horizontal and vertical reference: WGS-84 and EGM96. The heights were recalculated so that they could be compared with the heights given in the KRON86-NH. It should be noted that due to the 
extraction of height values from global DEM models with the accuracy of $1 \mathrm{~m}$, the impact of using different height systems was visible only for the Tatra peaks. Global data sources also include open databases: OpenStreetMap (OSM) and WikiData. Both databases, due to their nature (the ability to edit content by the users), are not treated as a source of primary data. The WikiData database is interesting due to the possibility of applying annotations to the entered heights. Due to their common use, both data sources should be included in the description of data sources used by the society. There is no single vertical reference adopted in both data sources, the users can provide values referenced to any system. For OSM, EGM96 is recommended, and the altitude in the Wikidata database can be given along with information about the vertical system used (for none of the peaks discussed in the article this information was given).

The official national GIS database for Poland is the State Register of Geographical Names, and for Slovakia, the ZBGIS database. The Polish database collects information on localities and physiographic objects, which also include mountain peaks [70]. In the first version of the database, the information on the height of the peaks was entered in the comments (in 2016). Currently, the Head Office of Geodesy and Cartography, which runs the database, recommends using the network service to determine the height available at: http:/ / services.gugik.gov.pl/nmt/ (accessed on 15 July 2021). The service allows one to determine heights using DEM from the ISOK project. Heights in the service and in the PRNG database are in the PL-KRON86-NH system. In the PRNG database, there are official locations of the highest points of the mountains, and in the web service one can check the heights of these points. The article uses the old version of the database and its current version using the web service. The Slovak ZBGIS is the official database for the geographic information system and contains information on mountain heights [71]. The database has the same elevation system as the Slovak LiDAR data discussed in previous subsections. As peak heights in ZB-GIS are given as rounded integers, the height conversion did not affect the given values. The heights from this data source are shown in Appendix $A$ in columns (7)-(14).

\subsection{Polish Civil and Military Topographic Maps}

A large group of sources used in the research are civilian and military topographic maps. The heights from these data sources are shown in Appendix A in columns (15)-(22). The following series were used from the Polish topographic maps:

- 1:10,000 in the PUWG 1965 coordinate system (10k 65)—civilian, (The abbreviation of the map series used in Appendix A is given in brackets)

- 1:10,000 in the PL-1992 (10k 92)—civilian,

- 1:25,000 in the PUWG 1965 (25k 65)-civilian,

- 1:50,000 in the PUWG 1965 (50k 65)—civilian,

- 1:50,000 in the PL-1992 (50k 92)—civilian,

- 1:50,000 in the UTM (50k WP)—military,

- $1: 50,000$ in the PUWG 1942 (50k LWP) - military,

- 1:100,000 in the PUWG 1942 (100k LWP)—military-civilian.

Civilian and military topographic maps from 1945-1989 (the period of the Polish People's Republic) were created mainly on the basis of a topographic survey of the country made in the scale of 1:10,000 in the years 1955-1970 [72]. These surveys were taken in the 1942 PUWG coordinate system, and then in the 1965 system. The earliest sheets were additionally updated until 1981. The civil service covered about $85 \%$ of Poland's territory, and the military service its remaining parts. Directly on the basis of the topographic photos, maps in the scale of 1:10,000 were created in the PUWG 1965 (10k 65) system. The development of the maps was completed in 1981, and their update was carried out in the years 1982-1991. Simultaneously with the work on the civilian map 1:10,000 in the years 1977-1992, maps 1:25,000 (25k 65) and 1:50,000 (50k 65) were developed. Depending on the sheet, the maps are valid for the 1970s, 1980s, and 1990s. 
From the beginning of the 1990s, new standards for topographic maps were developed. As a result of the work, from 1994, topographic maps were published in the PL-1992 system in the scale of $1: 10,000(10 \mathrm{k} 92)$ and 1:50,000 (50k 92). The map in the scale of 1: 50,000 has been developed by 2005 , reaching the coverage of approximately $50 \%$ of the country's area. The 1:10,000 map was issued continuously and as a derivative of the first modern topographic database since 2003. When publishing maps, their content was updated.

Military topographic maps in the scale of 1:50,000 in the PUWG 1942 coordinate system (50k LWP) (common for the entire Warsaw Pact) were created simultaneously with civil maps and were based on topographic photos in the scale of 1:10,000. Their validity dates back to the 1970s and 1980s. Even before Poland joined NATO, works began on the development of 1:50,000 topographic maps (50k WP) adapted to the NATO standard. The UTM grid was applied to the already developed maps, and from 1998 the maps were made directly in the UTM system. In the case of updating the spreadsheet, the content was updated for the 1990s and 2000s. The last series of Polish topographic maps is a series of maps in the scale of 1:100,000 (100k LWP), developed by the military service on the basis of military maps, but with additional civil tourist content. This makes these maps interesting in the light of the research area discussed in this article. These maps are valid for the 1980s and 1990s. All Polish and Slovak topographic maps have altitudes given in relation to the sea level in the Kronstadt system.

\subsection{Slovak Civil and Military Topographic Maps}

In 1953, a topographic mapping of the Czechoslovak Republic (SK TM 25) was initiated. As a basic method, regarding efficiency and accuracy, the universal photogrammetric method was used, which mapped almost $70 \%$ of the entire territory of the Czechoslovak Republic. Additionally, the method of revision of previous measurements, the combined method (photoplan, measuring table), and the marginal table method were used. To fulfil the tasks and goals of the mapping, all significant geodetic, topographic, and cartographic capacities from the military and partly also the civilian sector were concentrated (approximately 20\%). A new mapping of the whole territory was completed in a record short time, also on a European scale, in 1957 [73]. Military topographic maps (SK TM 25) were updated in the 1990s of the 20th century, here cited as RETM_25 (SK RETM 25) and RETM_50 (SK RETM 50). These are raster equivalents of the topographic map at 1:25,000 scale (resp. $1: 50,000)[74]$. The heights from this data source are shown in Appendix A in columns (23), (24), and (25).

\subsection{Books and Small-Scale Map Sources}

The article also analyses the peak heights given in books and maps covering and describing the entire Polish Carpathians [75-77]. The heights from this data source are shown in Appendix A in columns (26)-(28). The heights given in these sources are secondary to topographic maps and other tourist maps. Due to the year of publication of the books and maps, the altitude data used there probably referred to the sea level in the Kronstadt system.

\subsection{Old Maps}

Old maps constituted the last group of sources used in the article. The heights from this data source are shown in Appendix A in columns (29)-(33). The area of the Carpathians on the border between Poland and Slovakia was in the Austrian Empire before the World War I. Two series of maps used in the research come from this period. The Second Military Survey of the Habsburg Empire (II_MS), "Galicia and Bucovina” part, was carried out in the years 1861-1864. This series of maps contains 413 sheets and was developed by a total of 7 supervising directors, 44 surveyors and drafters, and 10 description writers [78]. Such a large number of contractors contributed to the differences between the sheets visible on their borders and in the labels on the map. Heights and distances on press studs were reported in Viennese fathoms [79] (1 Viennese fathoms $=1.896483840 \mathrm{~m}$ ). The maps 
were developed based on triangulation measurements. The redaction of the maps used cadastral maps in a 1:2880 scale and derived scales [17]. The Second Military Survey of the Habsburg Empire provided a model for all subsequent topographic maps compiled in the area, including the Carpathian Mountains. The Third Military Survey (III_MS) (1875-1884) was carried out using geodetic-astronomical measurements at the basic reference point Hermannskögel (near Vienna). These measurements, despite their errors corresponding to the state of measurement technology of their time and the measurement techniques used, were also used in the creation of the Unified Trigonometric Cadastral Network (JTSK) Ing. Josef Křovák (1884-1951) in the 1920s and 1930s, and in the form of cadastral maps are still used today [80]. Unfortunately, the original map sheets of the third military mapping of Slovakia were destroyed during the World War II [81] and only black-and-white copies have been preserved to the present day, the readability and clarity of which is further reduced by an inappropriate combination of height hatches and contour lines.

Another source for our work was maps of the Fourth Military Survey (IV_MS), which was carried out in Slovakia in the years 1896-1897 in the High Tatras. The preserved double sheet map is also unique in that the methods of ground photogrammetry were used for the first time during the mapping. The war events of the World War I and the subsequent disintegration of the Austro-Hungarian monarchy prevented further mapping. In 1931, a double sheet map of the High Tatras from the so-called Fourth Military Survey was updated [74].

The article also derived the peak heights from 1:100,000 maps prepared by the Military Geographical Institute (WIG_100) [82]. This map series is considered to be the pinnacle of Polish cartography of the interwar period. The maps in the scale of 1:100,000 were developed in the "Borowa Góra" layout and a quasi-stereographic projection of the WIG. The maps were rich in content and geometrically correct. At the beginning of their development, these maps were based on the Third Military Survey of the Habsburg Empire, and over the years they were updated with new measurements. The reference level for altitude was the mean North Sea level in Amsterdam [72]. The last series of maps discussed in the article were non-urban maps "Karte des Deutschen Reichs 1:100,000—Grossblätter" from 1940-1941, mostly based on Polish WIG maps and supplemented with new measurements (GROSSBLÄTTER).

What is more, the altitude measurements made for old maps used different reference levels which include the sea level in Amsterdam for WIG_100 and GROSSBLÄTTER maps (about $18 \mathrm{~cm}$ below the sea level in the Kronstadt system for the analysed area of the Polish Carpathians) and the Trieste sea level (about $34 \mathrm{~cm}$ below the Amsterdam sea level) for II_MS, II_MS and IV_MS map series. It was decided not to modify height data given on old maps due to their unequal accuracy, and small influence of different reference levels on height differences (for Austrian maps about $-0.5 \mathrm{~m}$ in relation to the sea level in the Kronstadt system).

\subsection{Study Area}

The research area covers 14 mountain ranges of the Polish Carpathians (Figure 1). These areas were designated taking into account the traditional division into mountain ranges (used, inter alia, in qualified tourism $[83,84]$ ) and taking into account the division into physico-geographical mesoregions (Table 1) [85]. The Carpathians are one of the highest mountain ranges in this part of the world. The state border between Poland and Slovakia runs through the Carpathian area and is $541 \mathrm{~km}$ long. Thanks to this, it was possible to analyse data sources from two countries. In small fragments, the border between Poland and Ukraine, as well as Poland and the Czech Republic, also runs through the Carpathian area. The Carpathians are not a single mountain range, but rather a series of adjoining and distinguishable mountain ranges. The Carpathian peaks, unlike the Alps, rarely reach the height of more than $2500 \mathrm{~m}$. Researchers have studied the Carpathians from the beginning of science, which is related not only to their natural wealth [86], topography [87], but also constant changes in land use [88]. 


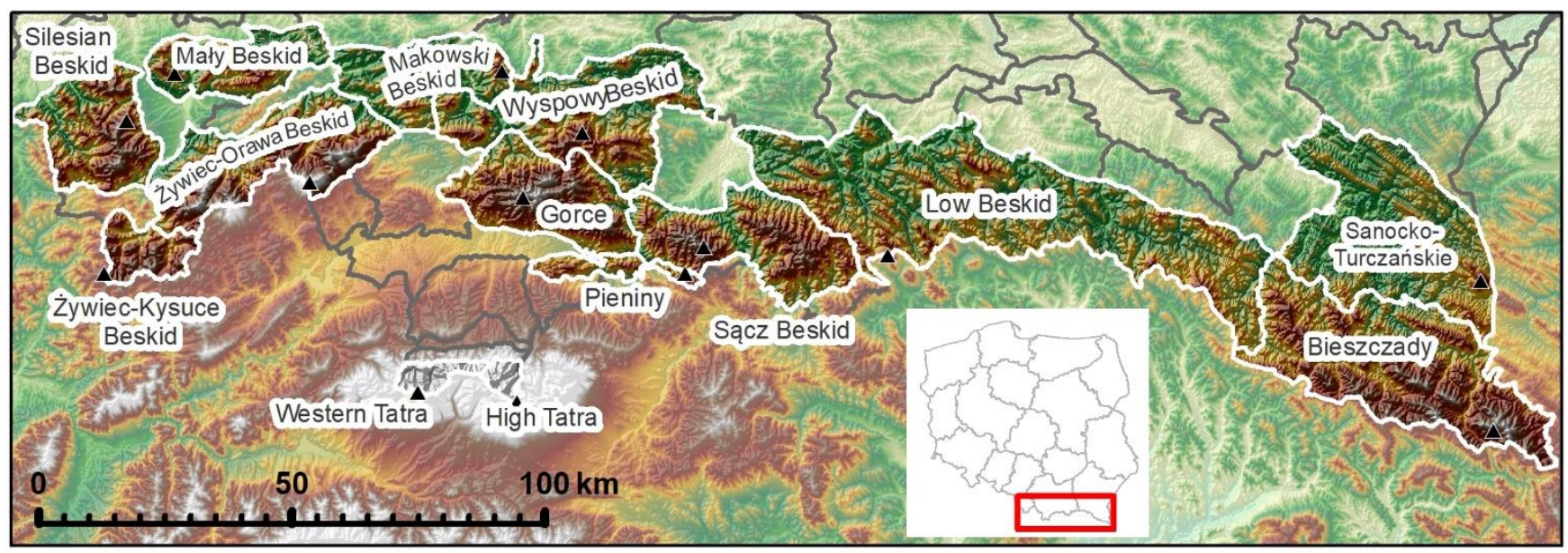

Figure 1. Study area-14 mountain ranges of the Polish Carpathians. Source: authors.

Table 1. Physico-geographical region classification of the study area. Subprovinces (bolded names), macroregions (italicised names), and mesoregions.

\begin{tabular}{cccc}
\hline $\mathbf{5 1 3}$ & Outer Western Carpathians & $\mathbf{5 1 4 - 1 5}$ & $\begin{array}{c}\text { Central Western } \\
\text { Carpathians }\end{array}$ \\
\hline $513.4-5$ & Western Beskidy Mts & 514.1 & Orawa-Podhale Basin \\
513.45 & Silesian Beskid Mts & 514.12 & Pieniny Mts \\
513.47 & Mały Beskid Mts & 514.5 & Tatra Range \\
513.48 & Makowski Beskid Mts & 514.52 & Western Tatra Mts \\
513.49 & Wyspowy Beskid Mts & 514.53 & High Tatra Mts \\
\cline { 3 - 4 } 513.51 & Żywiec-Orawa Beskid Mts & $\mathbf{5 2 2}$ & Outer Eastern Carpathians \\
513.52 & Gorce Mts & 522.1 & Lesiste Beskidy Mts \\
513.54 & Sacz Beskid Mts & 522.11 & Sanocko-Turczańskie Mts \\
513.56 & Żywiec-Kysuce Beskid Mts & 522.12 & Bieszczady Mts \\
513.7 & Mid-Beskidy Mts & & \\
513.71 & Low Beskid Mts & & \\
\hline
\end{tabular}

The peaks analysed in the article are mostly located in protected areas: five peaks are located in national parks or their buffer zones, another five peaks are located in landscape parks or their buffer zones; three peaks are also located in nature reserves. Only three peaks (Jaworniki, Lackowa and Lubomir) are not located in a protected area. Eight peaks are covered with forest, the rest are in open space. Some of the peaks are very popular tourist destinations (Rysy, Babia Góra), and others are not widely known (especially Jaworniki in the Sanocko-Turczańskie Mts).

\section{Results}

\subsection{GNSS-Geodetic}

The results of GNSS geodetic measurements in the article were treated as reference for other data sources. GNSS surveying has the smallest error of all the sources and methods used. The differences in height, visible in the graphs in Appendix B, were calculated according to the Formula (1):

$$
\mathrm{dH}_{\mathrm{i}}=\mathrm{H}_{\mathrm{i}}-\mathrm{H}_{\mathrm{GNSS}},
$$

where:

$\mathrm{H}_{\mathrm{GNSS}}$ - height from GNSS surveying-Appendix A, column (1),

$\mathrm{H}_{\mathrm{i}}$-height measured with a given method or derived from a given source-Appendix A, columns (2)-(33). 


\subsection{Slovak LiDAR-Analyses}

The analysis of Slovak LiDAR was performed in relation to the Polish LiDAR data and was conducted for two peaks-Rysy and Starorobociański Wierch, due to the Slovak data extent. The first step of the analysis covered determining the highest points classified as Ground in all .las datasets. For Rysy, it was necessary to limit the results to the boundaries of Poland (the Slovak peak of Rysy is higher). The highest point of Starorobociański Wierch is also located on the territory of Slovakia; however, this is a single peak expanding from Poland. The highest Ground points for particular datasets are summarised in Table 2. The digits in the names correspond to the four last digits of downloaded datasets. The location of points is presented in Figure 2, in relation to the location of summits derived from the OpenStreetMap database.

Table 2. The highest points in Slovak ALS datasets classified as Ground.

\begin{tabular}{cccc}
\hline \multicolumn{3}{c}{ Rysy } \\
\hline X PL-1992 [m] & Y PL-1992 [m] & H KRON86 [m] \\
\hline LAS 1416 & 579273.31 & 146355.86 & 2499.53 \\
LAS 0351 & 579271.57 & 146354.95 & 2499.33 \\
LAS 1788 & 579271.07 & 146354.57 & 2499.32 \\
LAS 2157 & 579271.67 & 146355.26 & 2499.32 \\
\hline \multicolumn{5}{c}{ Starorobociański Wierch } \\
\hline LAS 0094 & 559714.40 & 148307.06 & 2175.87 \\
\hline
\end{tabular}

Source of ALS products: ÚGKK SR.
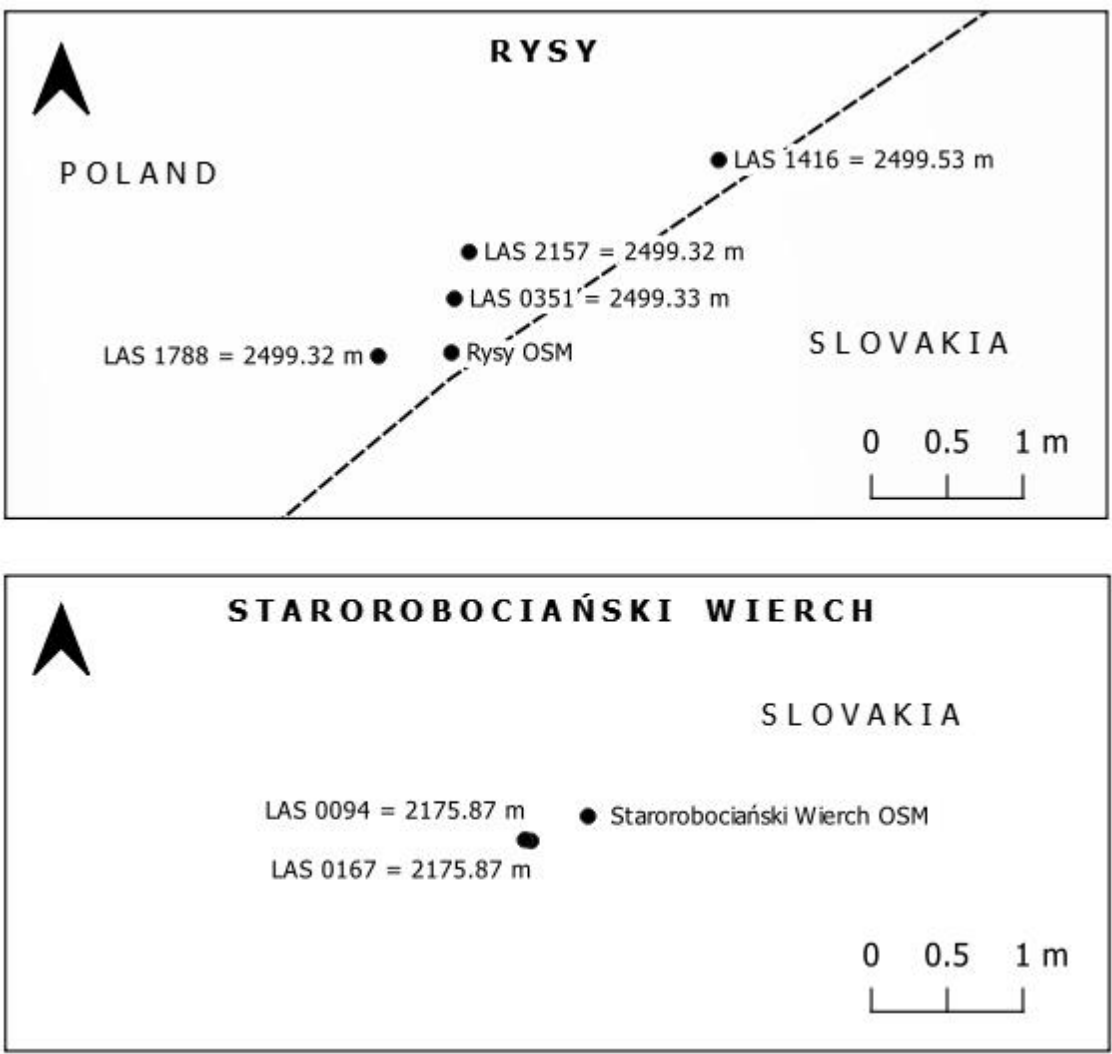

Figure 2. Location of the highest Ground points in relation to OSM (OpenStreetMap) peaks. Source: authors.

The outcomes of this analysis show high consistency between different las datasets covering the same region. For Rysy. There is one outlier, differing by more than $20 \mathrm{~cm}$ 
from other values, which is probably a misclassification error, as the summit is a popular hiking destination among tourists during summer season. In other cases, the differences among the highest Ground points did not exceed $1 \mathrm{~cm}$. The highest point in the vicinity of Rysy (LAS 0351) and a probable misclassification error (LAS 1416) were presented in CloudCompare (Figure 3)

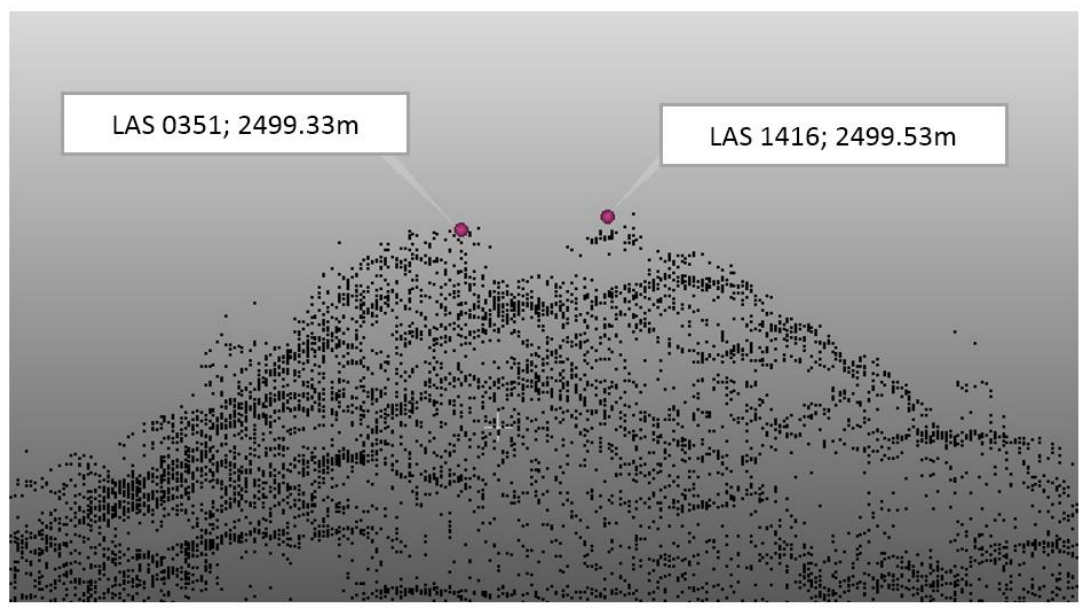

Figure 3. Rysy and the two highest Ground points detected in point clouds. Source: authors.

In order to further examine the point clouds, their density was calculated in LAStools. Then, the classes of points within a radius of $1 \mathrm{~m}$ from the OSM summit were analysed (for Rysy the results were limited to the points located in Poland). Finally, distances between the highest point in each class and the OSM summit were calculated (Table 3).

Table 3. Slovak point clouds density, the analysis of points within a radius of $1 \mathrm{~m}$ from the OSM peak.

\begin{tabular}{|c|c|c|c|c|c|}
\hline Peak & Dataset & Classification & $\begin{array}{l}\text { Number of } \\
\text { Points }\end{array}$ & $\begin{array}{c}\text { The Highest } \\
{[\mathrm{m}]}\end{array}$ & $\begin{array}{l}\text { Distance from the } \\
\text { Peak [m] }\end{array}$ \\
\hline \multirow{14}{*}{ RYSY } & \multirow{3}{*}{$\begin{array}{c}\text { LAS 2157, } \\
\text { Density }=8.93 \mathrm{pts} / \mathrm{m}^{2}\end{array}$} & Ground & 26 & 2499.32 & 0.7 \\
\hline & & Unclassified & 8 & 2500.15 & 0.1 \\
\hline & & Total & 34 & - & - \\
\hline & \multirow{3}{*}{$\begin{array}{c}\text { LAS } 1788, \\
\text { Density }=9.75 \mathrm{pts} / \mathrm{m}^{2}\end{array}$} & Ground & 31 & 2499.32 & 0.5 \\
\hline & & Unclassified & 1 & 2499.34 & 0.3 \\
\hline & & Total & 32 & - & - \\
\hline & \multirow{5}{*}{$\begin{array}{c}\text { LAS 0351, } \\
\text { Density }=9.56 \mathrm{pts} / \mathrm{m}^{2}\end{array}$} & Ground & 22 & 2499.33 & 0.4 \\
\hline & & Unclassified & 7 & 2500.17 & 0.3 \\
\hline & & $\begin{array}{c}\text { Medium } \\
\text { vegetation }\end{array}$ & 2 & 2499.71 & 0.9 \\
\hline & & Low vegetation & 1 & 2499.03 & 1 \\
\hline & & Total & 32 & - & - \\
\hline & \multirow{3}{*}{$\begin{array}{c}\text { LAS } 1416, \\
\text { Density }=7.96 \mathrm{pts} / \mathrm{m}^{2}\end{array}$} & Ground & 14 & 2499.27 & 0.6 \\
\hline & & Unclassified & 10 & 2499.64 & 0.9 \\
\hline & & Total & 24 & - & - \\
\hline \multirow{6}{*}{$\begin{array}{c}\text { STAROROBOCIAŃSKI } \\
\text { WIERCH }\end{array}$} & \multirow{3}{*}{$\begin{array}{c}\text { LAS 0094, } \\
\text { Density }=6.18 \mathrm{pts} / \mathrm{m}^{2}\end{array}$} & Ground & 24 & 2175.87 & 0.4 \\
\hline & & Low vegetation & 3 & 2175.82 & 0.5 \\
\hline & & Total & 27 & - & - \\
\hline & \multirow{3}{*}{$\begin{array}{c}\text { LAS 0167, } \\
\text { Density }=6.60 \mathrm{pts} / \mathrm{m}^{2}\end{array}$} & Ground & 28 & 2175.87 & 0.4 \\
\hline & & Low vegetation & 2 & 2175.79 & 0.5 \\
\hline & & Total & 30 & - & - \\
\hline
\end{tabular}


The results for the single points and the DTM models are also presented in Appendix A and in Figure A1 in Appendix B.

The results suggest that during the ALS flights there were people or their equipment on the summit (unclassified points). LAS 1788 dataset seems to be the least affected by this factor, as there is only one unclassified point and there are no outliers. Several mistakes can be seen in LAS 0351 dataset, as there is no vegetation at all at the peak of Rysy. After these analyses, the point clouds covering the same location were merged in order to make comparisons with the Polish datasets. The final density of last-return points in the merged point clouds was $35.97 \mathrm{pts} / \mathrm{m}^{2}$ for Rysy and $16.29 \mathrm{pts} / \mathrm{m}^{2}$ for Starorobociański Wierch.

\subsection{Polish LiDAR-Analyses}

Polish LiDAR data were downloaded for free from the national Geoportal [65] in PL-1992 coordinate system, with KRON86-NH heights. These were two sections (one for Rysy and one for Starorobociański Wierch) which then were clipped to the same extent as Slovak data sets. Next, the point clouds were converted to .txt format and loaded to QGIS 3.10.3 as a CSV layer with known geometry. Then, the highest points classified as Ground in the area of Rysy and Starorobociański Wierch were detected (Table 4). For Starorobociański Wierch there are two values because the highest one did not correspond well to the location of the peak derived from OSM and Slovak datasets, hence it is believed to be an error.

Table 4. Location and height of the highest Ground points in Polish datasets.

\begin{tabular}{|c|c|c|c|c|}
\hline Peak & $\begin{array}{l}\text { X PL-1992 } \\
{[\mathrm{m}]}\end{array}$ & $\begin{array}{l}\text { Y PL-1992 } \\
{[\mathrm{m}]}\end{array}$ & $\begin{array}{c}\text { H KRON86 } \\
{[\mathrm{m}]}\end{array}$ & $\begin{array}{l}\text { Distance from the Peak } \\
{[\mathrm{m}]}\end{array}$ \\
\hline RYSY & $579,271.18$ & $146,354.96$ & 2500.01 & 0.5 \\
\hline $\begin{array}{c}\text { STAROROBOCIAŃSKI } \\
\text { WIERCH }\end{array}$ & $559,711.60$ & $148,310.39$ & 2175.83 & 4.5 \\
\hline $\begin{array}{c}\text { STAROROBOCIAŃSKI } \\
\text { WIERCH }\end{array}$ & $559,714.01$ & $148,306.63$ & 2175.78 & 1 \\
\hline
\end{tabular}

Next, the density of point clouds in clipped extents was calculated and the analysis of points within a radius of $1 \mathrm{~m}$ from the peak was conducted (Table 5). RGB colour was read from the datasets to eliminate potentially misclassified points, with colours which do not appear naturally in high mountains. Such a situation was not identified, all detected Ground points were in grey shades.

Table 5. Polish point clouds' density, the analysis of points within a radius of $1 \mathrm{~m}$ from the OSM peak.

\begin{tabular}{|c|c|c|c|c|c|}
\hline Peak & Dataset & Classification & $\begin{array}{l}\text { Number of } \\
\text { Points }\end{array}$ & $\begin{array}{c}\text { The Highest } \\
{[\mathrm{m}]}\end{array}$ & $\begin{array}{c}\text { Distance from the } \\
\text { Peak }[\mathrm{m}]\end{array}$ \\
\hline \multirow{2}{*}{ RYSY } & \multirow{2}{*}{ Density $=6.95 \mathrm{pts} / \mathrm{m}^{2}$} & Ground & 19 & 2500.01 & 0.5 \\
\hline & & Total & 19 & - & - \\
\hline \multirow{5}{*}{$\begin{array}{l}\text { STAROROBOCIAŃSKI } \\
\text { WIERCH }\end{array}$} & \multirow{5}{*}{ Density $=7.62 \mathrm{pts} / \mathrm{m}^{2}$} & Ground & 7 & 2175.78 & 1 \\
\hline & & Low vegetation & 20 & 2175.98 & 0.5 \\
\hline & & Medium vegetation & 3 & 2175.92 & 0.5 \\
\hline & & Never classified & 1 & 2175.40 & 0.8 \\
\hline & & Total & 31 & - & - \\
\hline
\end{tabular}

The results for the single points and the DTM models are also presented in Appendix A and in Figure A1 in Appendix B. 


\subsection{Slovak and Polish LiDAR—Comparison}

The comparison of Slovak and Polish datasets was divided into two parts-numerical and visual. The numerical comparison involved such factors as: point cloud density, analysis of the highest Ground points in the vicinity of the peak, their location (Table 6).

Table 6. Results of numerical comparison of Slovak and Polish ALS datasets.

\begin{tabular}{|c|c|c|c|c|c|}
\hline \multicolumn{6}{|c|}{ RYSY } \\
\hline \multirow{2}{*}{ Dataset } & X PL-1992 [m] & Y PL-1992 [m] & \multirow{2}{*}{ H KRON-86 [m] } & \multirow{2}{*}{$\begin{array}{l}\text { point cloud density } \\
\left.\text { [pts } / \mathrm{m}^{2}\right]\end{array}$} & \multirow{2}{*}{$\begin{array}{c}\text { number of Ground points } \\
\text { within a } 1 \text { m radius }\end{array}$} \\
\hline & \multicolumn{2}{|c|}{ distance between points [m] } & & & \\
\hline SK & $579,271.57$ & $146,354.95$ & 2499.33 & 35.97 & 93 \\
\hline \multirow[t]{2}{*}{ PL } & $579,271.18$ & $146,354.96$ & 2500.01 & 6.95 & 19 \\
\hline & \multicolumn{2}{|c|}{0.39} & & & \\
\hline \multicolumn{6}{|c|}{ STAROROBOCIAŃSKI WIERCH } \\
\hline SK & $559,714.44$ & $148,307.05$ & 2175.87 & 16.29 & 52 \\
\hline \multirow[t]{2}{*}{ PL } & $559,714.01$ & $148,306.63$ & 2175.78 & 7.62 & 7 \\
\hline & \multicolumn{2}{|c|}{0.60} & & & \\
\hline
\end{tabular}

As can be seen in the tables, for Rysy, the highest Ground point was 2499.33 in the Slovak data set and 2500.01 in the Polish data set, which makes a difference of almost $0.7 \mathrm{~m}$. This is significant, especially because Rysy is the highest mountain in Poland. Slovak data seem to be more reliable in this case, as there were four separate Slovak point clouds available for this region, and on none of them such a value was detected. Furthermore, the density of a merged Slovak point cloud is almost six times higher than in the case of Polish ALS data (SK-35.97 pts $/ \mathrm{m}^{2}, \mathrm{PL}-6.95 \mathrm{pts} / \mathrm{m}^{2}$ ). The value in the Polish dataset is believed to be a misclassified point corresponding to tourist equipment laying at the peak. For Starorobociański Wierch the results are similar, varying only by $0.09 \mathrm{~m}$, and this value is lower than vertical accuracy of the analysed datasets. In this case, the Slovak point cloud is two times denser than the Polish one.

The visual part of comparison was performed in CloudCompare. First, the point clouds for both peaks (Rysy-Figure 4, Starorobociański Wierch-Figure 5) were displayed separately and the highest Ground points were identified. This was done both with only Ground class displayed (Figures $4 \mathrm{a}$ and $5 \mathrm{a}$ ) and with all point cloud classes displayed (Figures $4 \mathrm{~b}$ and $5 \mathrm{~b}$ ). Then, the points representing Ground class in Polish and Slovak datasets were displayed together (Figures $4 \mathrm{c}$ and $5 \mathrm{c}$ ).

As can be seen in the visual part of comparison, the point clouds from Poland and Slovakia are coincident. This was also checked in CloudCompare in cloud-to-cloud module. The mean distance between all points for Rysy is $0.13 \mathrm{~m}$ and for Starorobociański Wierch $-0.25 \mathrm{~m}$. In the visual analysis, the higher density of Slovak data is clearly visible. In the case of Rysy, it seems that the lower density of the Polish data affected the process of classification as the structure of ground is difficult to identify. Furthermore, especially in Slovak datasets, it is visible that the presence of people at the summit during scanning flights may affect classification process: some important points might not be included and some of them may be misclassified. This statement can be further supported by the photo of the summit during summer season (Figure 6).

In the case of Starorobociański Wierch, significant differences can be seen in classification. The Polish point cloud contains much more points not classified as Ground-mostly as Low vegetation while the corresponding points in the Slovak dataset are classified as Ground. The terrain at the peak is various-with rocks, bare land, and grass, which makes the process of classification more difficult and may result in errors. 

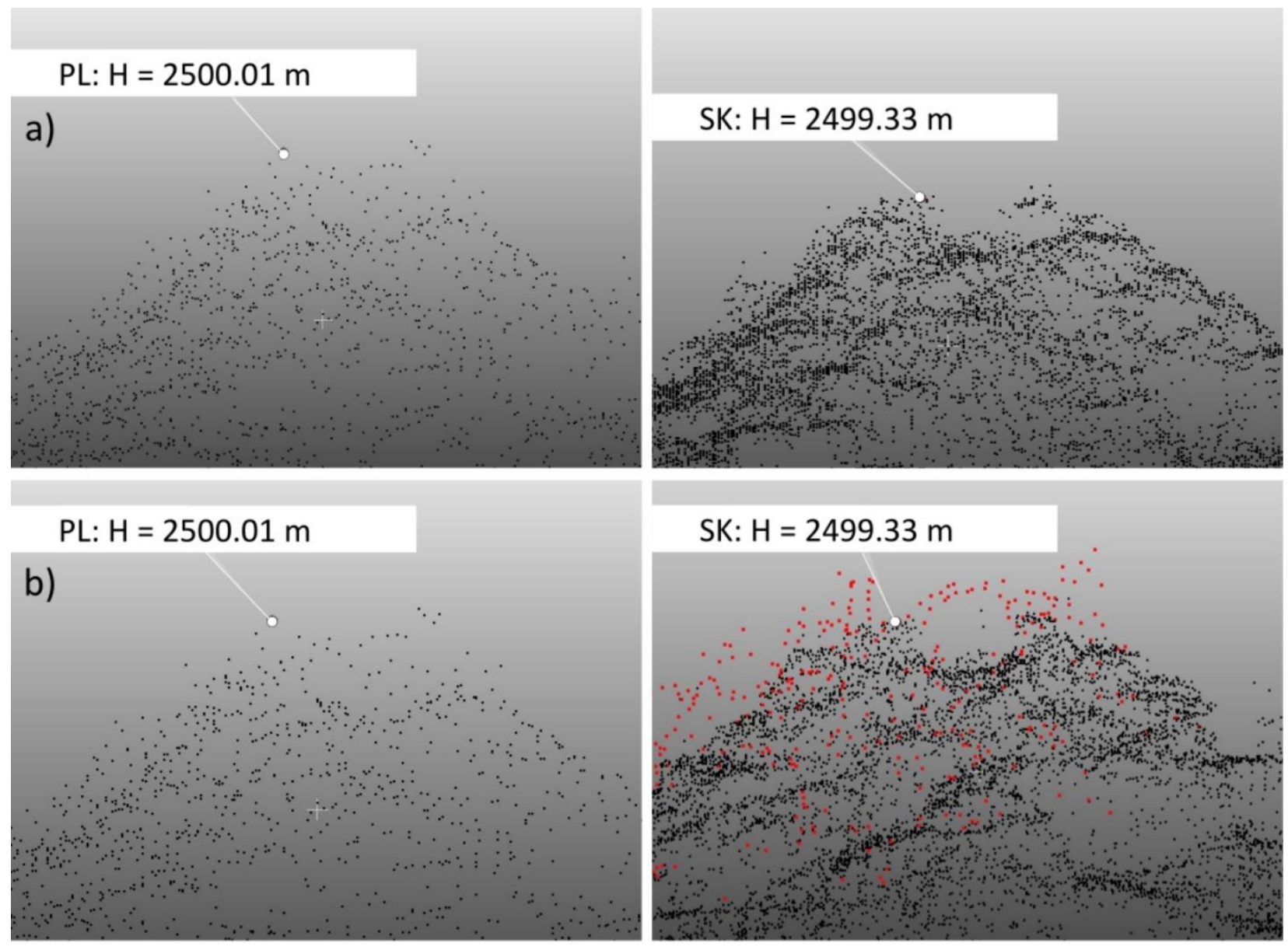

\section{c)}

\section{PL: $H=2500.01 \mathrm{~m}$}

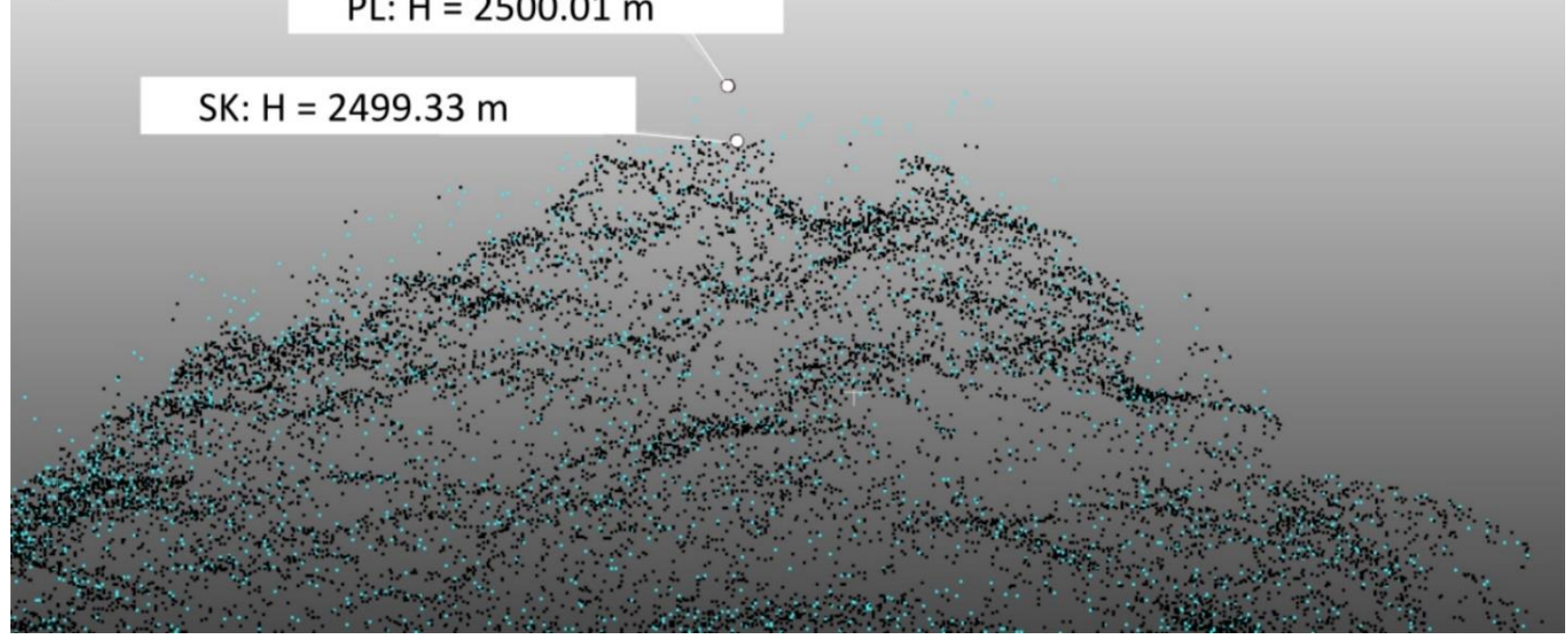

Figure 4. (a) The highest point on Rysy and Ground class, (b) the highest point at the peak and all other classes (black-Ground, red-others), (c) Polish (blue) and Slovak (black) datasets, Ground class. Source: authors. 

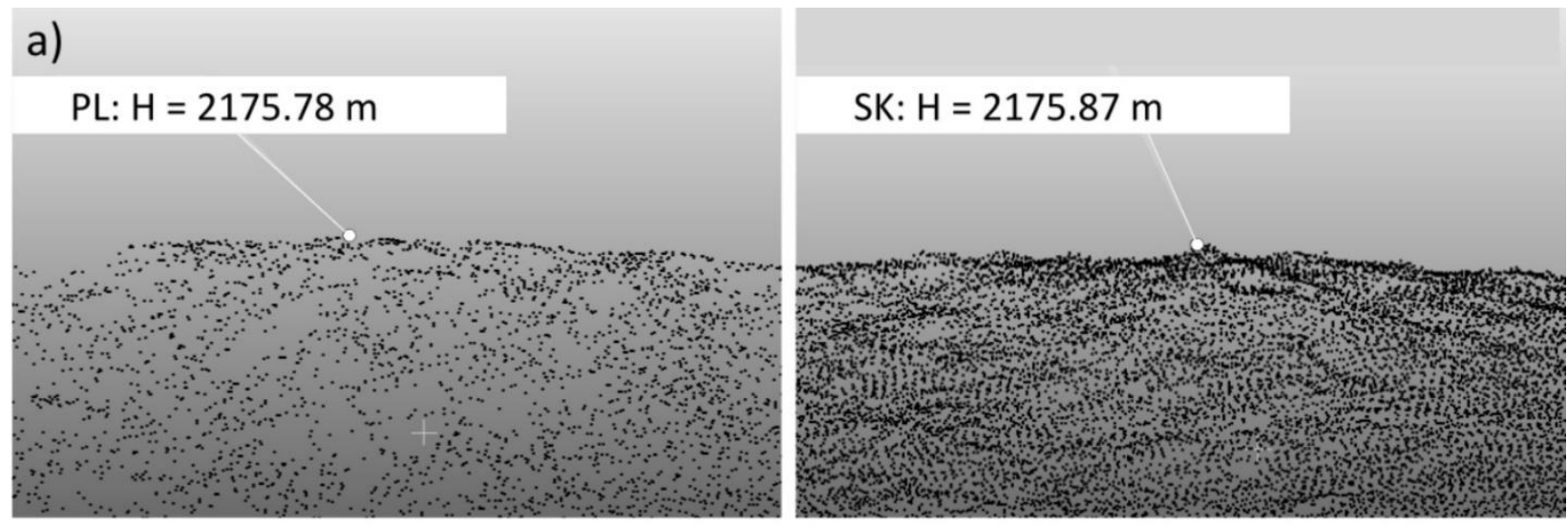

b)
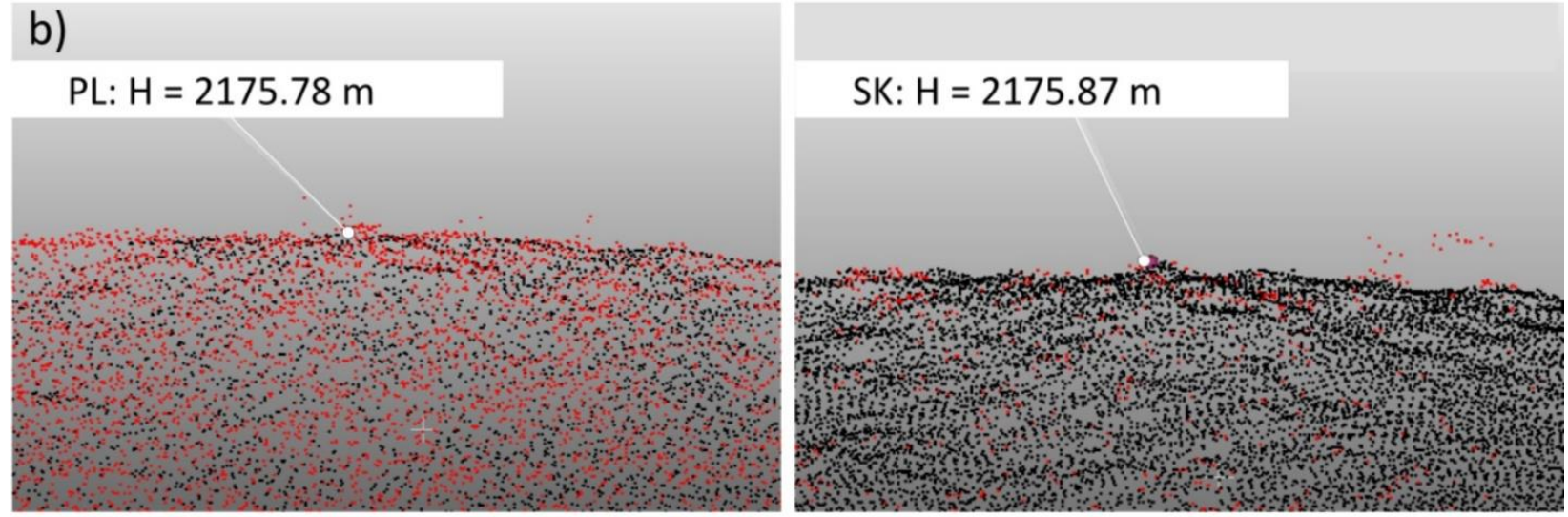

c)

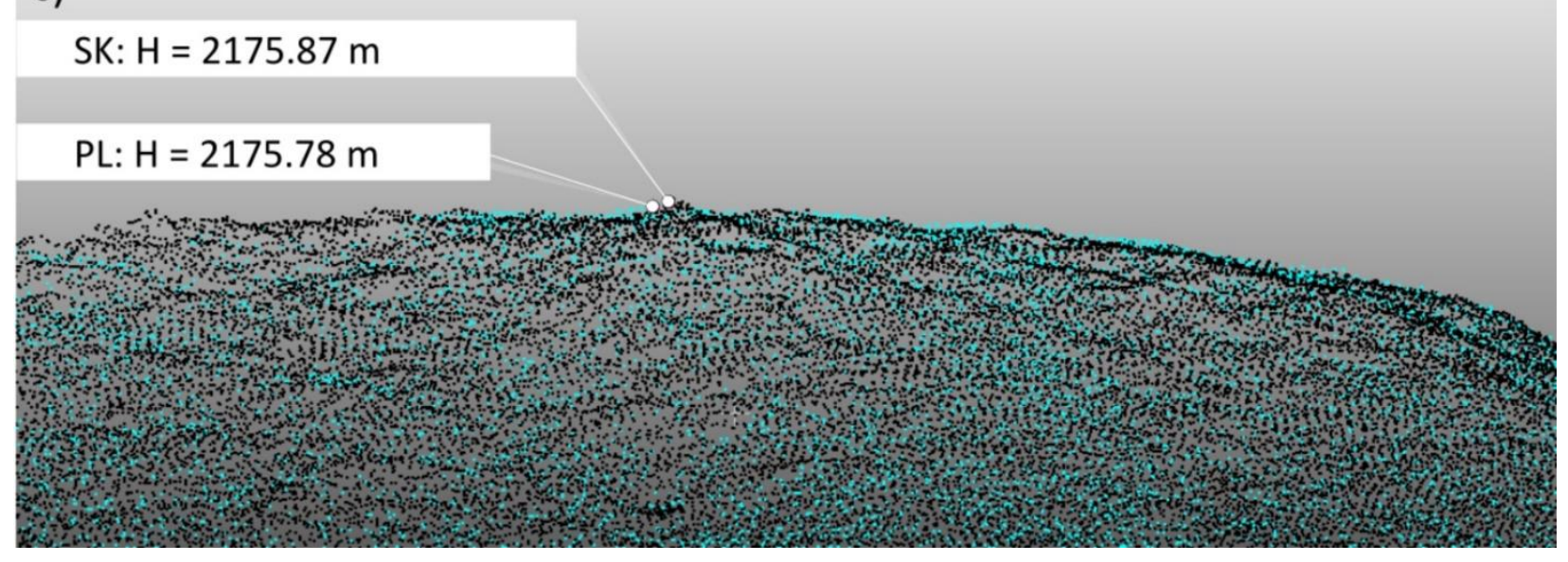

Figure 5. (a) The highest point on Starorobociański Wiech and Ground class, (b) the highest point at the peak and all other classes (black—Ground, red-others), (c) Polish (blue) and Slovak (black) datasets, Ground class. Source: authors.

\subsection{Smartphone GNSS Measurements}

Smartphone GNSS measurements were carried out on eight peaks. Normal heights $\mathrm{H}_{\mathrm{S}}$ calculated for the mountain peaks and their deviations $\mathrm{dH}_{\mathrm{S}}$ from the height values determined by RTK (or static) method are shown in Table 7.

Due to the low quality of phase observations, float solutions were obtained for all calculated GNSS vectors. In the case of smartphone phase measurements, the obtained accuracy of height determination can be considered promising but does not allow the use of mobile phones as target devices in this type of measurement. The results for the single points and the DTM models are also presented in Appendix A and in Figure A1 in Appendix B. 

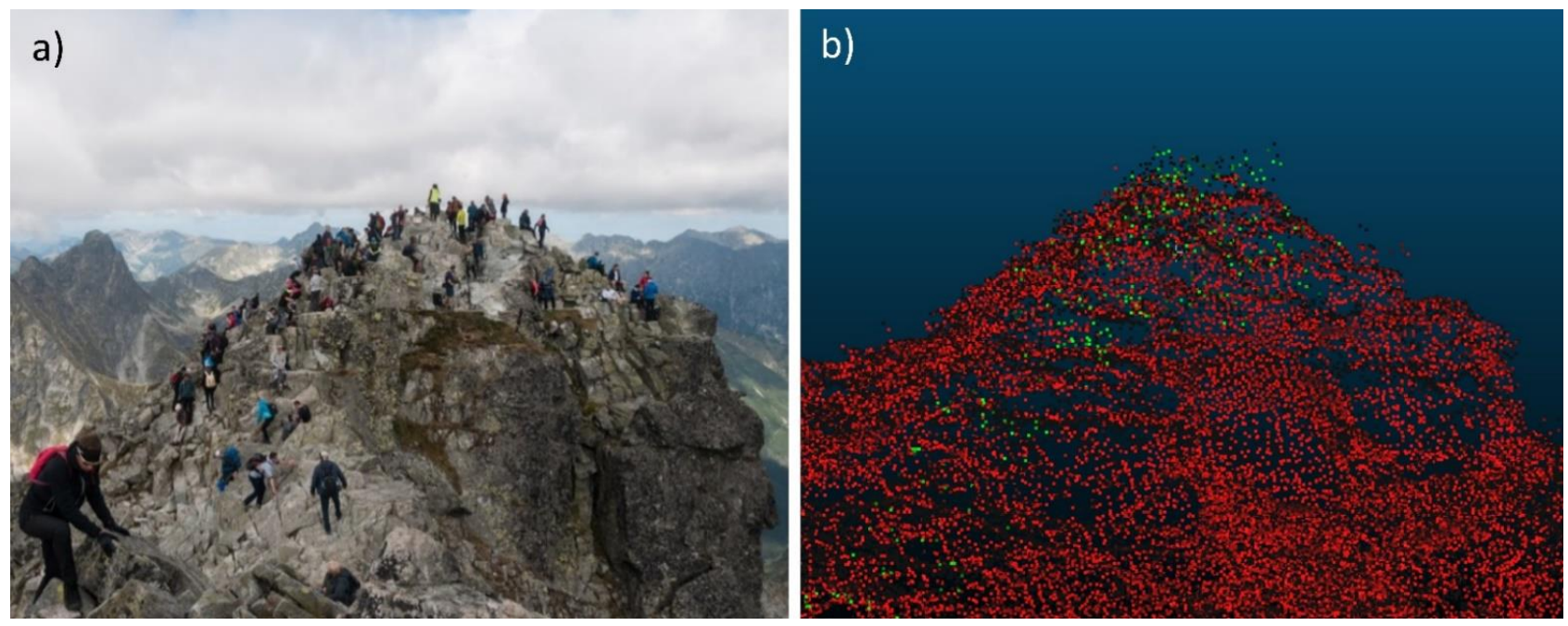

Figure 6. Rysy: (a) photo taken in summer season; (b) Slovak ALS point cloud with Unclassified (green) and Ground (red) points. Source: authors.

Table 7. Measurement results obtained with the Xiaomi Mi 8 smartphone.

\begin{tabular}{cccc}
\hline Peak & Mountain Range & $\mathbf{H}_{\mathbf{S}}[\mathbf{m}]$ & $\mathbf{d H}_{\mathbf{S}}[\mathbf{m}]$ \\
\hline Babia Góra & Żywiec-Orawa & 1723.8 & 0.2 \\
Lubomir & Beskid Mts & 903.9 & 0.3 \\
Czupel & Makowski Beskid Mts & 930.7 & 0.0 \\
Lackowa & Mały Beskid Mts & 998.3 & 0.4 \\
Radziejowa & Low Beskid Mts & 1261.6 & -0.5 \\
Mogielica & Sącz Beskid Mts & 1171.4 & -0.5 \\
Turbacz & Wyspowy Beskid Mts & 1309.8 & -0.1 \\
Wysoka Skała & Gorce Mts & 1049.5 & 0.2 \\
\hline
\end{tabular}

\subsection{Global DEMs, Databases, and Internet Sources}

The results for the single points and the DTM models are also presented in Appendix A and in Figures A2 and A3 in Appendix B. The mountain peak heights recorded in the PRNG database in 2016 came mainly from other data sources, including topographic maps. Therefore, similar values of differences can be seen within several series of topographic maps (compare, for example, Radziejowa and Turbacz). Comparing the positions of the peaks in PRNG with the network service provided by the Head Office of Geodesy and Cartography gave negative values of differences for all peaks. This is confirmed by the fact that the point representing the peak in the PRNG database is not located at its maximum height. This relationship is especially visible for Wysoka Skała in the Pieniny Mountains $(-13.4 \mathrm{~m})$. The heights of the peaks included in the Slovak ZBGIS database vary from about 1 metre to several metres. Interestingly, the largest negative value of difference was recorded for Starorobociański Wierch, which has an exposed peak without vegetation, with its maximum on the Slovak side of the border. For Internet data sources (OpenStreetMap and Wikidata), the differences in height of the peaks reach absolute values of about 2 and over $2 \mathrm{~m}$. Only for some peaks (Tarnica and Turbacz), the differences do not exceed $1 \mathrm{~m}$ in both sources.

The results for sources using global data models SRTM and Google Earth clearly show that the peak heights are underestimated. This is due to the need to cover the entire Earth with one algorithm. The smallest differences and positive values of differences can be observed in the GLO_30. This is probably due to the fact that the model is constantly being improved. This paper uses the version published in 2021. For 6 of the 14 peaks, the height differences are larger than $4 \mathrm{~m}$. Compared to other global DEM models, the difference 
values are both positive and negative. The biggest differences are in the model used in Google Earth because it is used mainly for data visualisation.

\subsection{Civilian and Military Topographic Maps (Polish and Slovak)}

The results for these data sources are presented in Appendix A and in Figures A4 and A5 in Appendix B. An interesting source of data are topographic maps in which several regularities can be observed. First of all, one can see the duplication of heights in different series of maps (e.g., for Turbacz, Radziejowa, Mogielica). One can also see the use of the same heights for border peaks for Poland and Slovakia in some series of maps (e.g., for Wysoka Skała, Babia Góra). This dependence is also visible in the SK RETM 50 map, the sheets of which extend further into the depths of Poland, and Polish topographic maps were used on them (e.g., for Radziejowa). One can also see that the series of 1:50,000 maps in the PL-1992 coordinate system from the 90s and 2000s has the smallest difference values. Unfortunately, this map series did not cover the entire study area. An interesting relationship can also be observed when looking at the height differences for Radziejowa. For this peak, from a certain point (map update in the 1980s), the altitude difference drops from over $4 \mathrm{~m}$ to $-0.3 \mathrm{~m}$. This shows that the map content was updated, including the update of peak heights. Interestingly, in the latest series of 1:50,000 military maps, the wrong height appears again, which in turn proves that many data sources, including those that are already out of date, are used in their creation.

\subsection{Books and Small-Scale Map Sources}

The results for these data sources are presented in Appendix A and in Figure A6 in Appendix B. Book data sources are characterised by fluctuating peak height differences. It can be seen that these sources are secondary to topographic maps. It can also be noticed that the authors used many data sources when creating them. The smallest values of differences (with the exception of Lubomir) can be noted for the book "Góry Polski" from 2006. Although it is not the most recent study, most of the differences in height do not exceed $1 \mathrm{~m}$.

\subsection{Old Maps}

The results for these data sources are presented in Appendix A and in Figure A7 in Appendix B. When analysing the differences in height for old maps, attention should be paid to the surprisingly (regarding the possibilities and techniques of that time) exact determination of heights of the peaks in the Third Military Survey of the Habsburg Empire. Some heights in the Second Military Survey were also determined accurately, but this should be considered a lucky coincidence rather than a regularity (given the errors for Turbacz and Lackowa). Maps of the interwar period and German maps from the World War II show the heights of the peaks for which the absolute values of differences usually do not exceed 5 metres (with a few exceptions, including Czupel, which was incorrectly marked on the map). It is a considerable surprise that peaks are included on the old maps that are now less known (e.g., Jaworniki), for which the heights are not always given, even on topographic maps older than 100 years.

\section{Discussion}

This paper presents a unique comparative study of 33 altitude data sources and its comprehensive analysis. The heights of 14 mountain peaks were analysed with reference to the authors' own GNSS geodetic measurements. The analysis was performed within various group of data sources. The most important ones were Polish and Slovak ALS point clouds and DTM models developed on their basis, and GNSS measurements conducted with smartphones. The analysis of point clouds is unique because of the in-depth description of points, potentially representing the highest point of mountain peak. For LiDAR data, de facto multiple points were analysed in contrast to other sources, for which these were mostly single values. The analysis of so many types of data sources, including historical 
ones, gives a broad view of their possible different applications. Topographic maps, global DEM models, and official or open databases can provide a valuable background for more accurate sources, which highlights their importance.

Analyses of Slovak and Polish LiDAR datasets show that although the data sets are consistent, differences in height are visible. Especially for the peak of Rysy, the Polish point cloud seems to be less reliable due to probable misclassification errors regarding a relatively low density of data, which is further supported by the visual analysis. Based on the results obtained for the peaks, it can be stated that the correct point classification is of key importance in terms of retrieving mountain height values. Classification is a highly demanding process, especially in tourist areas, where the presence of people might affect LiDAR data acquisition, as it was presented for the peak of Rysy.

As has been repeatedly noted in the literature, large-area LiDAR scanning can be used to obtain information about the height of field objects [60]. However, research to date has not focused on comparing point clouds for the purposes of determining the maximum height of mountain peaks. Moreover, LiDAR scanning technology used without an in-depth analysis may lead to erroneous conclusions. In 2020, new heights of the Tatra peaks were announced, retrieved from LiDAR point clouds from the ISOK project [89]. These heights were used in new Tatra maps. The authors of the aforementioned study did not conduct an in-depth analysis of point clouds. The analysis of the heights of point clouds at the top of Rysy presented in our article proves that in such specific conditions (high tourist traffic, rocks, steep slopes), using the point cloud with a density of $7 \mathrm{pts} / \mathrm{m}^{2}$ is not sufficient. For the majority of peaks, the heights read from the point cloud were underestimated, which was caused by missing the LiDAR point at the highest point of the terrain. Positive values of height differences, up to $0.5 \mathrm{~m}$, occur for peaks covered with high vegetation (Czupel); with tourist infrastructure, such as barriers, boards, etc. (Wysoka Skała); and with high tourist traffic (Rysy). The values of DTM heights in comparison to point clouds are smaller for individual peaks, and it can be noticed that the height decrease is greater for the peaks with positive difference values (Rysy, Czupel) than for the negative ones. This proves the minimisation of the impact of misclassified points on DTM values.

Currently, the accuracy and reliability of GNSS measurements conducted with smartphones is at the decimetre level. However, it should be noted that the use of raw GNSS measurements allows for the use of differential methods, or solutions in the PPP-Precise Point Positioning mode [52,90]. This leads to a significant increase in the accuracy of measurements compared to the methods previously used in positioning with smartphones. These methods were based on the use of an autonomous position calculated by the GNSS chipset software. This allowed for the accuracy of a few to several metres. In this study, the accuracy of determining heights of mountain peaks was obtained at the level of several decimetres (Appendix A column (6)). Such accuracy can be considered adequate to carry out a preliminary measurement, which will help to identify peaks, the height of which is significantly different from that shown in studied sources.

As for the other data sources, it should be stated that even the most recent of them do not allow for their collective application for the correct identification of the height of mountain peaks. It should be noted that the data sources described and analysed in the article are at different levels of generalisation. Drawing far-reaching conclusions about the quality of whole models based solely on the results presented in the article may lead to erroneous findings. Thus, the comparison with geodetic GNSS measurements was made to illustrate height differences with the most accurate data source. We were particularly interested in comparing other data sources in groups: topographic maps, global DEM models, databases, historical maps, etc. The conclusions that we draw are related only to the height information recorded in the individual sources, and do not refer to the quality of entire sources.

Global models usually present lower heights and the differences amount to several dozen metres. A known fact from the literature is that the absolute vertical accuracy of the SRTM model varies from a few to several metres, depending on the terrain cover [91]. 
This was also confirmed by this study. It should be noted, however, that there is no simple relationship between, terrain coverage and the height differences for selected models. Considering the height differences (shown in the figures), the Copernicus DEM 30 m model is considered as the best one of global models presented in this paper.

Currently available topographic maps are much more accurate in terms of the heights of the peaks, which is important because topographic maps are the source maps for tourist maps. However, their content should be approached critically, due to the possible duplication of erroneous values. The analysis of 11 series of Polish and Slovak topographic maps conducted in this paper clearly illustrated the problem of duplication of measurement errors on topographic maps. Thanks to the joint compilation of the results, the variation of height errors is also visible. For example, the height given for Turbacz is the height of an obelisk (triangulation point) located at the top. Differences smaller than one metre may result from the applied calculation methods and/or adapted rounding.

Even official databases contain peak heights with incorrect values. Thanks to including in the article less reliable data sources (open databases: OSM and Wikidata), an interesting fact could be observed-some peaks in such data sources may contain more accurate values than these presented on topographic maps or stored in other official databases. Old maps are an interesting source of data on peak heights. They give a picture of changes in measurement techniques and can be surprisingly accurate.

\section{Conclusions}

Although LiDAR data may potentially reflect terrain relief very well, it is hard to treat them as referential, with no background knowledge and other control analyses. ALS data may be affected by numerous factors, which may result in errors in final outcomes. These are, for example, people or other equipment in the scanning area, misclassification during data processing, low point cloud density, etc. One should always bear in mind that some summits might be covered with vegetation, which also results in higher vertical errors. We believe this method should not be used without a prior in-depth analysis of data sets, and to ensure the highest accuracy, it should be accompanied by direct measurements. However, point clouds may undeniably serve as valuable data sources, especially in times when numerous countries make these data freely accessible.

Due to the portability of smartphones, their use in mountainous conditions would be particularly beneficial. However, at present, the quality of smartphone GNSS phase measurement is insufficient to obtain high accuracy in height determination. Accuracies currently obtained are at the level of decimetres. Such accuracy allows for the use of smartphones only for the initial identification of mountain peaks, the height of which significantly differs from that indicated in the verified sources.

Summarising the research presented in the article, it should be stated that large-area LiDAR scanning and DTM models can be used in the updating of mountain peaks altitude. For particularly important peaks, such as the highest one in a given mountain range or the entire country, it is necessary to use additional GNSS geodetic measurements. Smartphonebased GNSS measurements can be used to detect gross errors in existing data sources.

The results presented in the article show that DTM models and point clouds from ALS can be used in horizontal positioning. Vertical coordinates are affected by errors depending on many factors, but also on the specificity of the mountain peak. The example of Rysy shows that even advanced classification algorithms can be unreliable in the case of peaks with increased tourist traffic. Other data sources may only be used to a limited extent. Due to the specificity of land cover, accurate GNSS surveys are still not available in many places, limiting their potential exploration by professional service robots, including field robots and personal service robots.

Future research should focus on all mountain ranges all around the globe. There are possibly other cartographic misrepresentations and inaccuracies in scores of popular peaks around the globe and rectifying erroneous information like this is vital to any mountainfocused science. 
Author Contributions: Conceptualization, S.S., M.R., K.K., K.M., B.S., J.K., T.L. and M.A.; methodology, S.S., M.R., K.K., K.M., B.S., J.K., T.L. and M.A.; software, S.S., M.R., K.K., K.M., B.S., J.K., T.L. and M.A.; validation, S.S., M.R., K.K., K.M., B.S., J.K., T.L. and M.A.; formal analysis, S.S., M.R., K.K., K.M., B.S., J.K., T.L. and M.A.; investigation, S.S., M.R., K.K., K.M., B.S., J.K., T.L. and M.A.; resources, S.S., M.R., K.K., K.M., B.S., J.K., T.L. and M.A.; data curation, S.S., M.R., K.K., K.M., B.S., J.K., T.L. and M.A.; writing-original draft preparation, S.S., M.R., K.K., K.M., B.S., J.K., T.L. and M.A.; writing-review and editing, S.S., M.R., K.K., K.M., B.S., J.K., T.L. and M.A.; visualization, S.S. and M.R.; supervision, S.S., K.K. and K.M.; project administration, S.S., K.K. and K.M.; funding acquisition, S.S., K.K. and K.M. All authors have read and agreed to the published version of the manuscript.

Funding: This research was funded by the AGH University of Science and Technology statutory fund 16.16.150.545 in 2021, the 'Setka w Koronie. Korona Gór Polski na 100-lecie AGH' project (http: / / koronagor.agh.edu.pl/, accessed on 1 June 2021) and grant POIR.04.01.04-00-0108/19 'Automated system for precise volume measurements-VolumeMonit'.

Institutional Review Board Statement: Not applicable.

Informed Consent Statement: Not applicable.

Data Availability Statement: All data mentioned in the text are available in Appendix A.

Acknowledgments: We gratefully acknowledge the four anonymous reviewers and the editor for thoughtful comments and suggestions which contributed significantly to the quality of the manuscript.

Conflicts of Interest: The authors declare no conflict of interest. 
Appendix A

Table A1. The peak heights in each data source. The sources are discussed and described in Section 3.

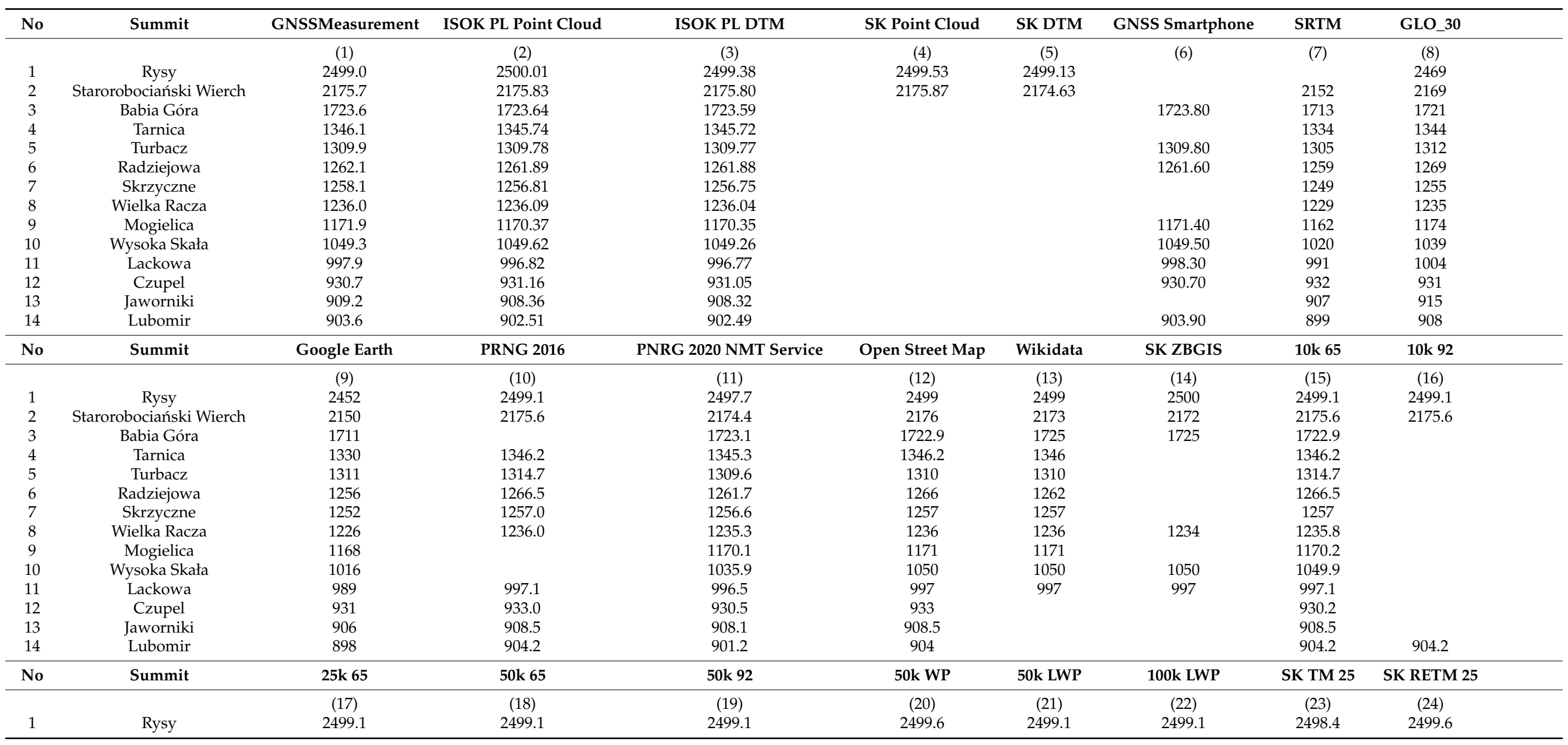


Table A1. Cont.

\begin{tabular}{|c|c|c|c|c|c|c|c|c|c|c|}
\hline 2 & Starorobociański Wierch & 2175.6 & 2175.6 & 2175.6 & 2175.6 & 2172.7 & 2175.6 & 2172.4 & 2172.7 & \\
\hline 3 & Babia Góra & 1722.8 & 1722.9 & 1723.4 & 1723.4 & 1722.9 & 1722.9 & 1724.8 & 1722.9 & \\
\hline 4 & Tarnica & 1346.2 & & & 1346.2 & 1346.2 & 1346.2 & & & \\
\hline 5 & Turbacz & 1314.7 & & & 1314.7 & 1314.7 & 1314.7 & & & \\
\hline 6 & Radziejowa & 1266.5 & 1261.8 & & 1266.5 & 1261.8 & 1261.8 & & & \\
\hline 7 & Skrzyczne & 1257 & 1257 & 1257 & 1257 & 1257 & 1257 & & & \\
\hline 8 & Wielka Racza & 1235.8 & 1235.8 & 1235.8 & 1235.8 & 1235.8 & 1235.8 & 1235.8 & 1236.1 & \\
\hline 9 & Mogielica & 1170.1 & & & 1170.2 & 1170.2 & 1170.1 & & & \\
\hline 10 & Wysoka Skała & 1049.9 & & & 1050 & 1049.9 & 1049.9 & 1050.1 & 1049.8 & \\
\hline 11 & Lackowa & 997.1 & & & 997 & 997 & 997.1 & 997 & 996.4 & \\
\hline 12 & Czupel & 930.2 & & & 930.2 & 930.2 & 898.8 & & & \\
\hline 13 & Jaworniki & 908.5 & & & 908.5 & 908.5 & 908.5 & & & \\
\hline 14 & Lubomir & 904.2 & 904.2 & & 904.2 & 904.2 & 904.2 & & & \\
\hline No & Summit & SK RETM 50 & $\begin{array}{c}\text { Encyklopedia } \\
\text { Polskich Karpat }\end{array}$ & Góry Polski & $\begin{array}{l}\text { Karpaty: Mapa } \\
\text { Wakacyjna }\end{array}$ & II_MS & III_MS & IV_MS & WIG_100 & GROSSBLÄTTER \\
\hline & & (25) & (26) & (27) & (28) & (29) & (30) & (31) & $(32)$ & (33) \\
\hline 1 & Rysy & 2499.6 & 2502 & 2499 & 2499 & & 2508 & 2503 & 2499.2 & \\
\hline 2 & Starorobociański Wierch & 2172.7 & 2176 & 2176 & & & 2170.6 & & 2175.6 & \\
\hline 3 & Babia Góra & 1722.9 & 1725 & 1725 & 1725 & 1721.7 & 1724.6 & & 1724.6 & 1724.6 \\
\hline 4 & Tarnica & 1346.2 & 1346 & 1346 & 1346 & 1328.2 & 1348 & & 1348 & 1348 \\
\hline 5 & Turbacz & & 1310 & 1310 & 1310 & 1065.5 & 1310.7 & & 1310.7 & 1316.7 \\
\hline 6 & Radziejowa & 1261.8 & 1266 & 1262 & 1262 & 1266.3 & 1265 & & 1265 & 1265 \\
\hline 7 & Skrzyczne & & 1257 & 1257 & 1257 & 1249.7 & 1250.2 & & 1250 & 1250 \\
\hline 8 & Wielka Racza & 1236.1 & & 1236 & 1236 & 1233.7 & 1236 & & 1236 & 1235 \\
\hline 9 & Mogielica & & 1170 & 1171 & 1179 & 1169 & 1170.8 & & 1170.8 & 1170.8 \\
\hline 10 & Wysoka Skała & 1049.8 & 1050 & 1050 & & 1048 & 1051.8 & & 1052 & 1052 \\
\hline 11 & Lackowa & 996.4 & 997 & 997 & 997 & 1048.2 & 999.5 & & 1001 & 1000.6 \\
\hline 12 & Czupel & & 933 & 933 & 933 & & 933 & & 903 & 933 \\
\hline 13 & Jaworniki & & & & & 903.2 & 910.3 & & 910 & 910 \\
\hline 14 & Lubomir & & 904 & 912 & 904 & $\begin{array}{c}883.3 \\
(921.2)\end{array}$ & $912 ?$ & & 912 & 912 \\
\hline
\end{tabular}




\section{Appendix B}

Peak height differences for data sources.

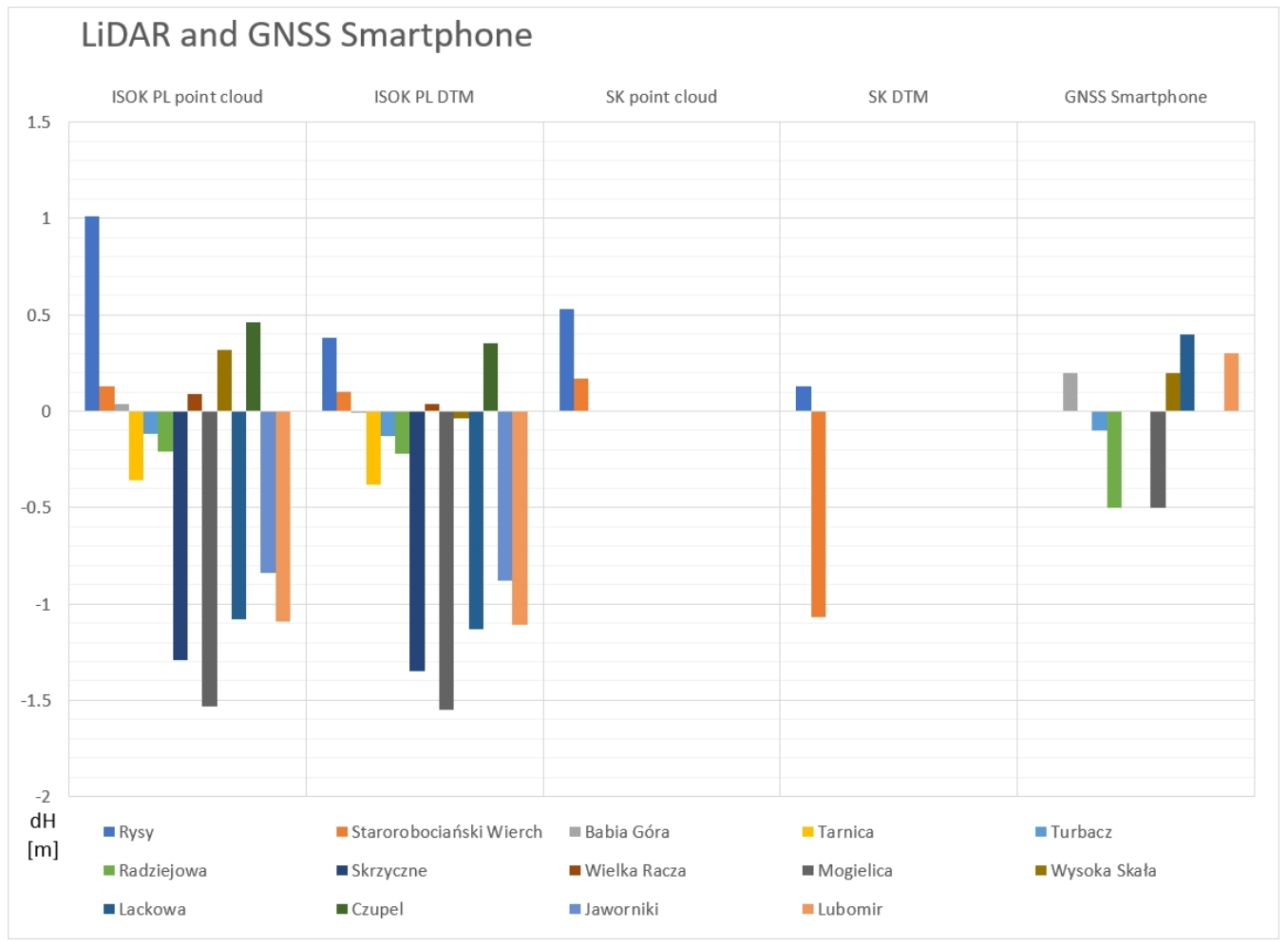

Figure A1. Height difference with GNSS surveying for point clouds, DTM models, and smartphone GNSS survey. Source: authors.

Global DEMs, databases and internet sources (part 1)

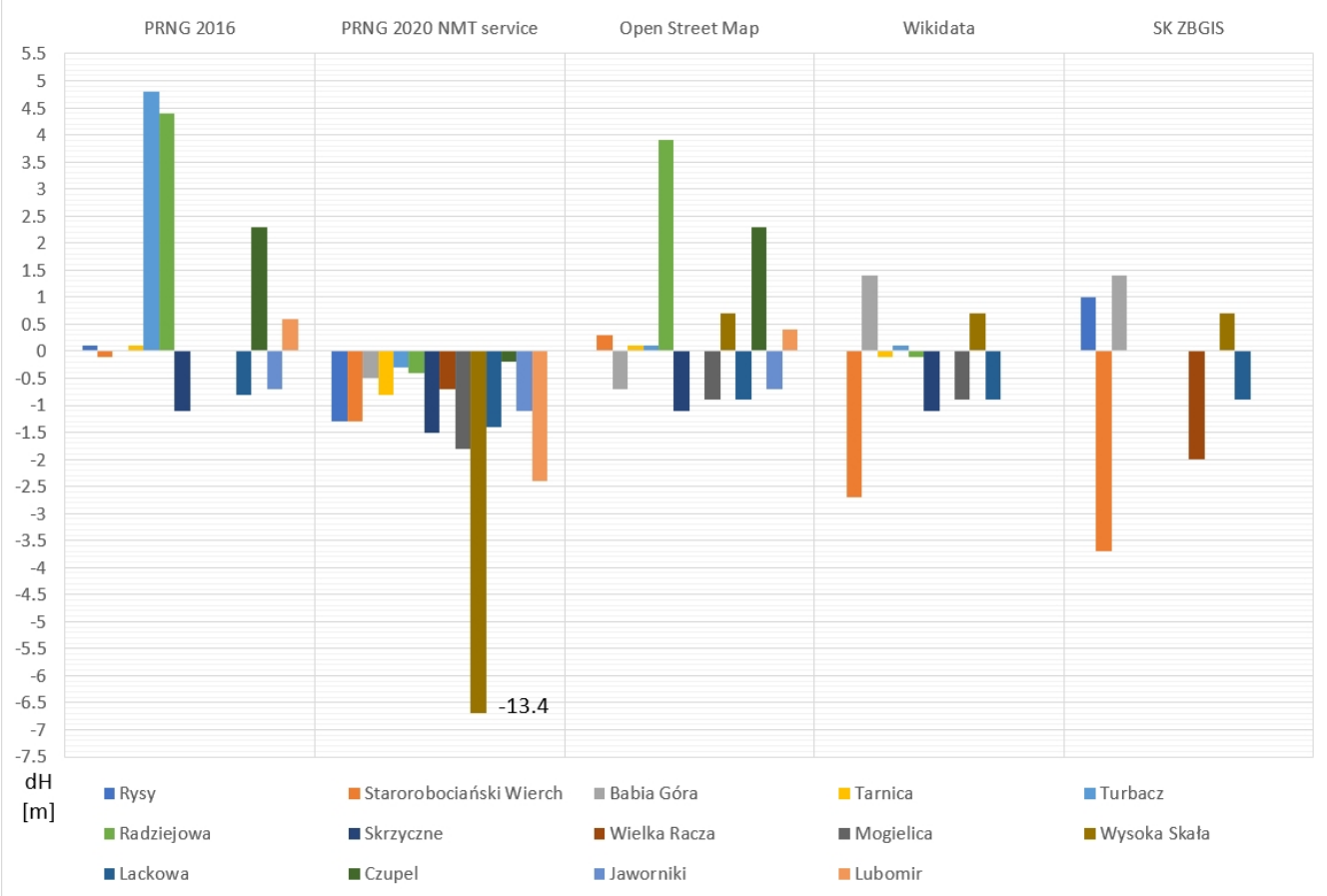

Figure A2. Height difference with GNSS surveying for Global DEMs, databases, and Internet sources (part 1). Source: authors. 


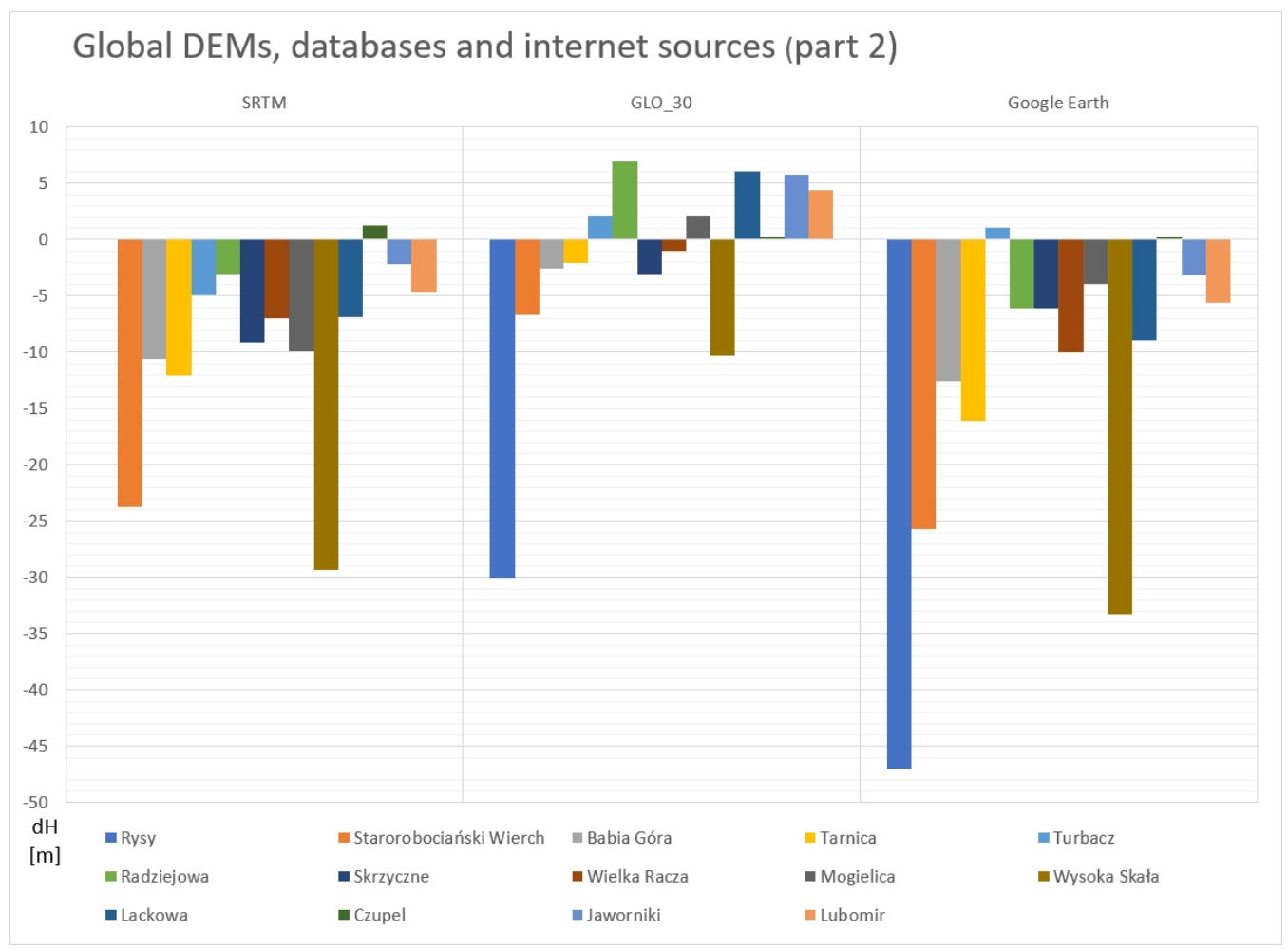

Figure A3. Height difference with GNSS surveying for Global DEMs, databases, and Internet sources (part 2). Source: authors.

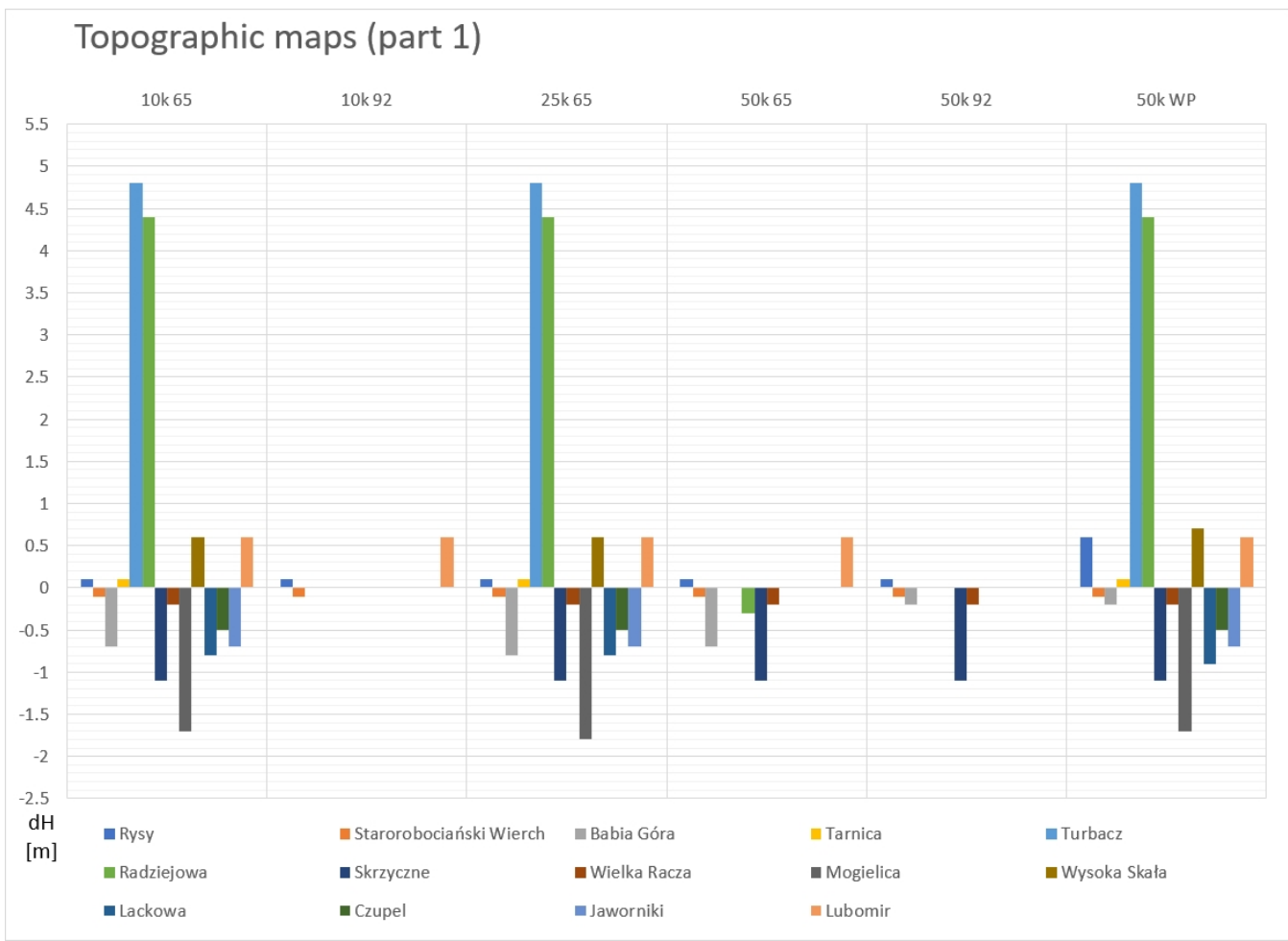

Figure A4. Height difference with GNSS surveying for civil and military topographic maps (Polish and Slovak) (part 1). Source: authors. 


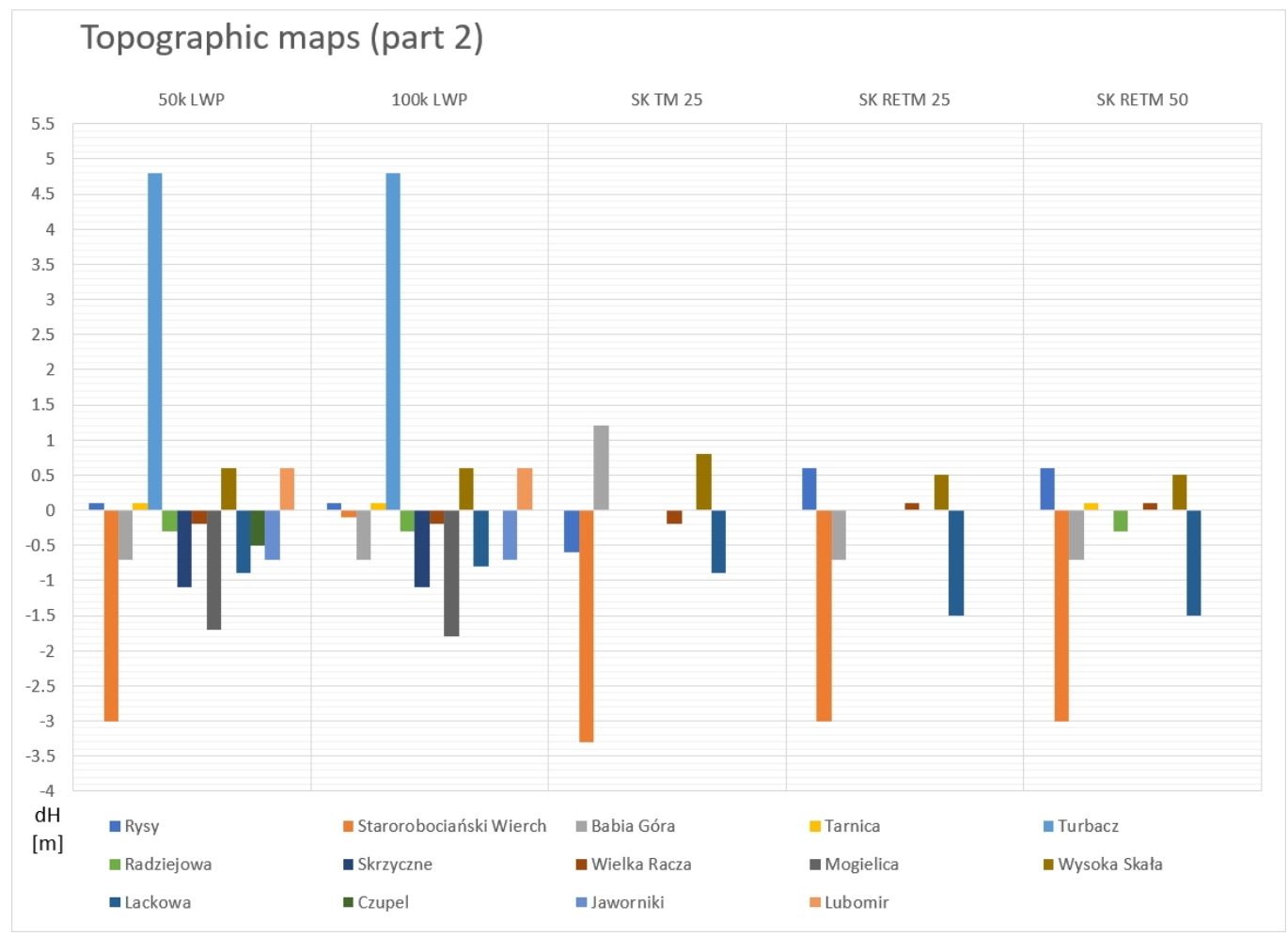

Figure A5. Height difference with GNSS surveying for civil and military topographic maps (Polish and Slovak) (part 2). Source: authors.

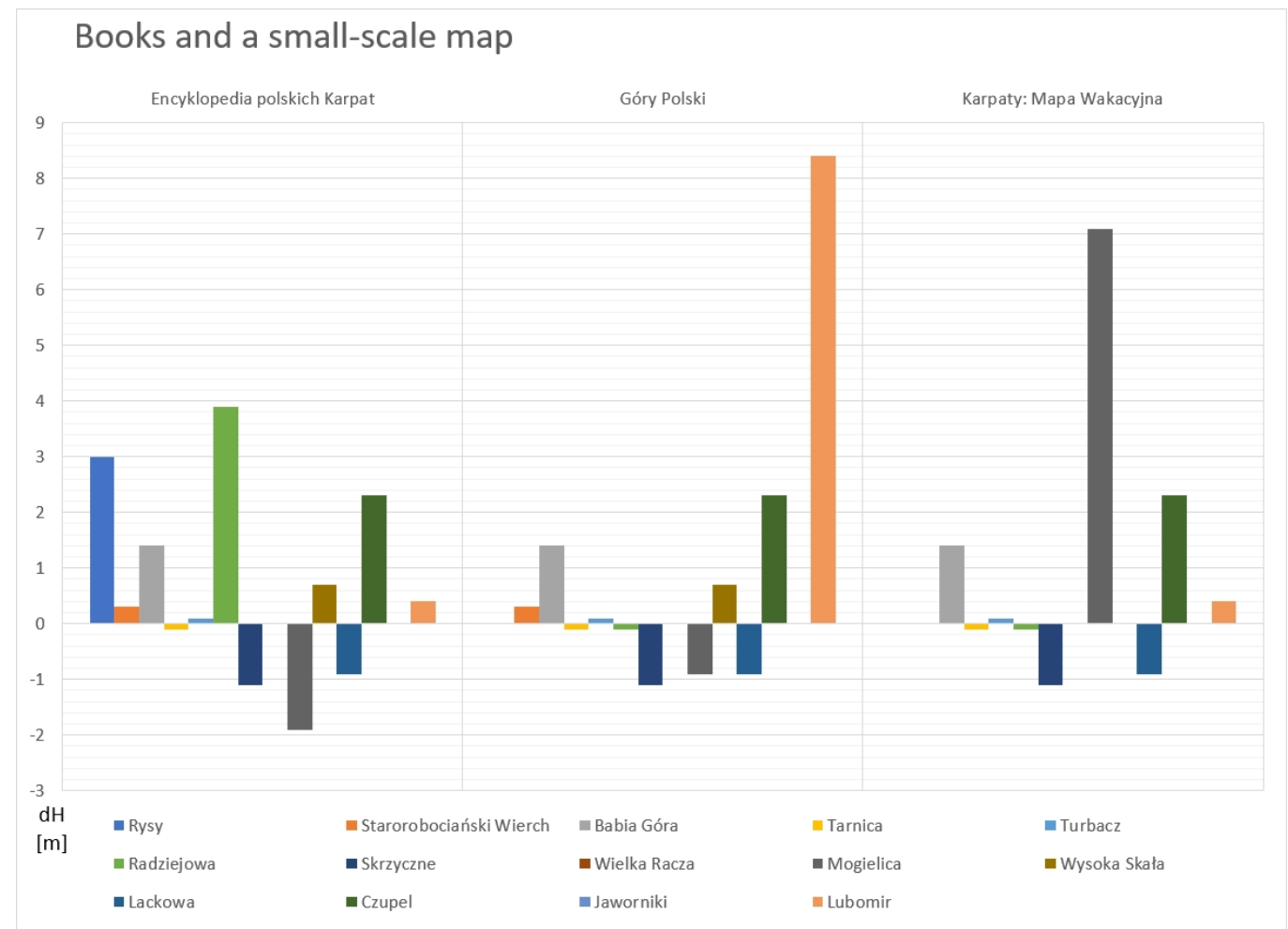

Figure A6. Height difference with GNSS surveying for book and small-scale map sources. Source: authors. 


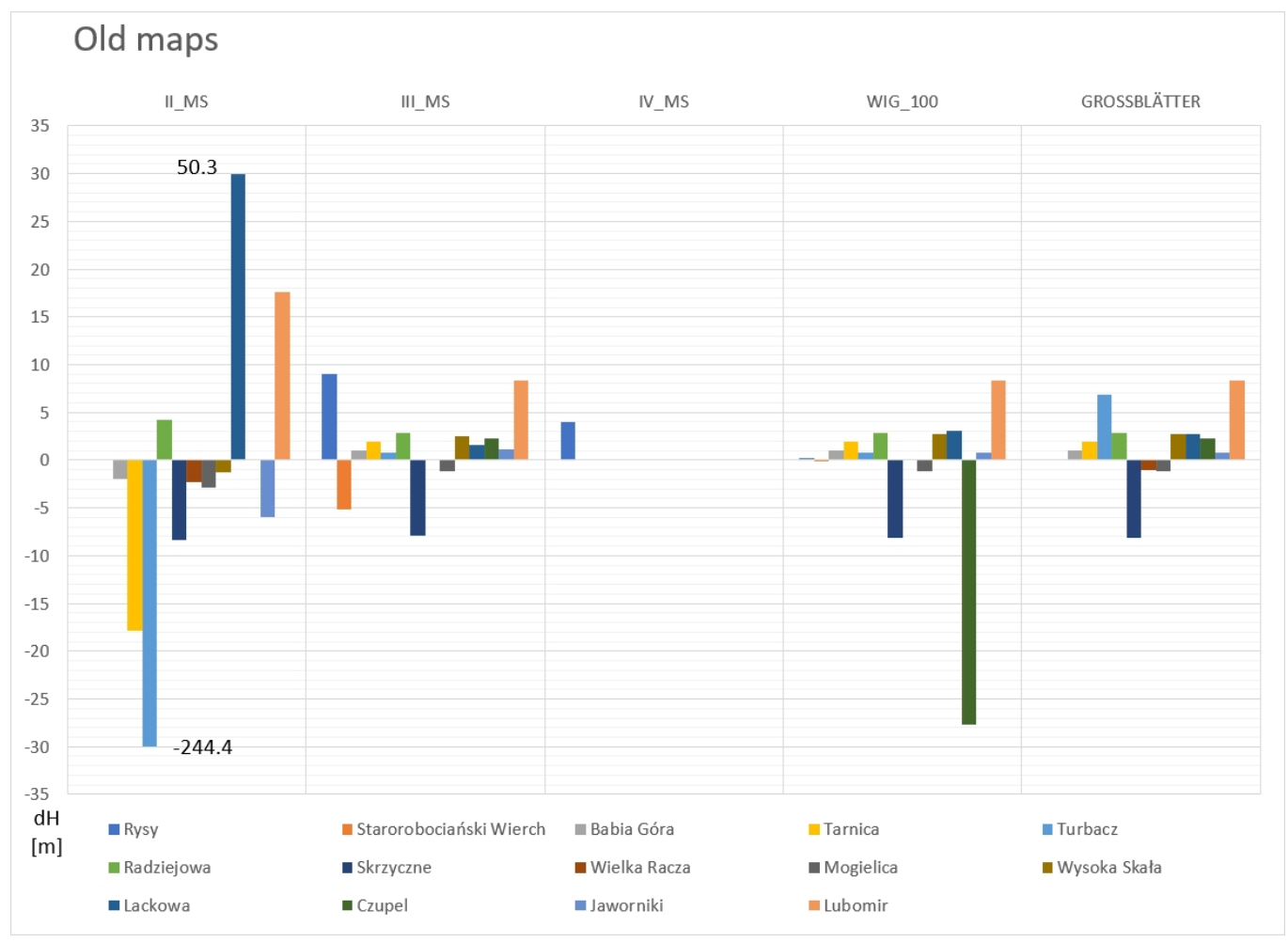

Figure A7. Height difference with GNSS surveying for old maps. Source: authors.

\section{References}

1. Cajori, F. History of Determinations of the Heights of Mountains. Isis 1929, 12, 482-514. [CrossRef]

2. Makowska, A. Precyzyjna niwelacja trygonometryczna w terenach górskich. Pr. Inst. Geod. Kartogr. 1986, 37, 193-220.

3. Lambrecht, A.; Mayer, C.; Wendt, A.; Floricioiu, D.; Völksen, C. Elevation change of Fedchenko Glacier, Pamir Mountains, from GNSS field measurements and TanDEM-X elevation models, with a focus on the upper glacier. J. Glaciol. 2018, 64, 637-648. [CrossRef]

4. $\quad$ Ching, K.E.; Hsieh, M.L.; Johnson, K.M.; Chen, K.H.; Rau, R.J.; Yang, M. Modern vertical deformation rates and mountain building in Taiwan from precise leveling and continuous GPS observations, 2000-2008. J. Geophys. Res. Solid Earth 2011, 116, 2000-2008. [CrossRef]

5. Webster, T.L.; Dias, G. An automated GIS procedure for comparing GPS and proximal LIDAR elevations. Comput. Geosci. 2006, 32, 713-726. [CrossRef]

6. $\quad$ Rieg, L.; Wichmann, V.; Rutzinger, M.; Sailer, R.; Geist, T.; Stötter, J. Data infrastructure for multitemporal airborne LiDAR point cloud analysis-Examples from physical geography in high mountain environments. Comput. Environ. Urban. Syst. 2014, 45, 137-146. [CrossRef]

7. Xiong, L.; Wang, G.; Bao, Y.; Zhou, X.; Sun, X.; Zhao, R. Detectability of repeated airborne laser scanning for mountain landslide monitoring. Geoscience 2018, 8, 469. [CrossRef]

8. $\quad$ Radebaugh, J.; Lorenz, R.D.; Kirk, R.L.; Lunine, J.I.; Stofan, E.R.; Lopes, R.M.C.; Wall, S.D. Mountains on Titan observed by Cassini Radar. Icarus 2007, 192, 77-91. [CrossRef]

9. Germann, U.; Galli, G.; Boscacci, M.; Bolliger, M. Radar precipitation measurement in a mountainous region. Q. J. R. Meteorol. Soc. 2006, 132, 1669-1692. [CrossRef]

10. Khanal, A.K.; Delrieu, G.; Cazenave, F.; Boudevillain, B. Radar remote sensing of precipitation in high mountains: Detection and characterization of melting layer in the grenoble valley, french Alps. Atmosphere 2019, 10, 784. [CrossRef]

11. Hopkinson, C.; Hayashi, M.; Peddle, D. Comparing alpine watershed attributes from LiDAR, Photogrammetric, and Contourbased Digital Elevation Models. Hydrol. Process. 2009, 23, 451-463. [CrossRef]

12. Müller, J.; Gärtner-Roer, I.; Thee, P.; Ginzler, C. Accuracy assessment of airborne photogrammetrically derived high-resolution digital elevation models in a high mountain environment. ISPRS J. Photogramm. Remote Sens. 2014, 98, 58-69. [CrossRef]

13. Lewińska, P.; Dyczko, A. Thermal Digital Terrain Model of a Coal Spoil Tip-A Way of Improving Monitoring and Early Diagnostics of Potential Spontaneous Combustion Areas. J. Ecol. Eng. 2016, 17, 170-179. [CrossRef]

14. Egholm, D.L.; Nielsen, S.B.; Pedersen, V.K.; Lesemann, J.E. Glacial effects limiting mountain height. Nature 2009, 460, 884-887. [CrossRef]

15. Angus-Leppan, P.V. The height of mount everest. Surv. Rev. 1982, 26, 367-385. [CrossRef] 
16. Khadka, N.S. Mt Everest Grows by Nearly a Metre to New Height. Available online: https://www.bbc.com/news/world-asia55218443 (accessed on 21 April 2021).

17. Romanyshyn, I.; Hajdukiewicz, M. The Height Survey of Mount Łysica in The Context of Verification of Geodesical and Cartographic Studies. Struct. Environ. 2019, 11, 153-164. [CrossRef]

18. Hajdukiewicz, M.; Romanyshyn, I. An accuracy assessment of spot heights on Digital Elevation Model (DEM) derived from ALS survey: Case study of Łysica massif. Struct. Environ. 2016, 9, 125-132.

19. Kuraś, B. Spór o Wysokość Rysów. Mamy Szczyt Sięgający 2500 m n.p.m.? Available online: https://krakow.wyborcza.pl/ krakow /7,174989,26240427,mamy-szczyt-siegajacy-2500-m-n-p-m.html?disableRedirects=true (accessed on 21 April 2021).

20. Stäuble, S.; Martin, S.; Reynard, E. Historical Mapping for Landscape Reconstruction Historical Mapping for Landscape Reconstruction Examples from the Canton of Valais (Switzerland). In Proceedings of the 6th ICA Mountain Cartography Workshop, Mountain Mapping and Visualisation, ETH Zurich, Institute of Cartography, Lenk, Switzerland, 11-15 February 2008; pp. 211-217.

21. Berczi, S. Reminiscent of an old book: "Critical review of minerals from Transylvania" by A. Koch, Kolozsvár, 1885: Proofs for the existence of anorthite-spinel-garnet peridotite series of inclusions in basalts of the Persányi Mountains Transylvania, Roumania. Acta Mineral. Petrogr. 1987, 29, 139-143.

22. Migoń, P.; Kasprzak, M.; Traczyk, A. How high-resolution DEM based on airborne LiDAR helped to reinterpret landformsExamples from the Sudetes, SW Poland. Landf. Anal. 2013, 22, 89-101. [CrossRef]

23. Gu, C.; Clevers, J.G.P.W.; Liu, X.; Tian, X.; Li, Z.; Li, Z. Predicting forest height using the GOST, Landsat 7 ETM+, and airborne LiDAR for sloping terrains in the Greater Khingan Mountains of China. J. Photogramm. Remote Sens. 2018, 137, 97-111. [CrossRef]

24. Hopkinson, C.; Demuth, M.N. Using airborne lidar to assess the influence of glacier downwasting on water resources in the Canadian Rocky Mountains. Can. J. Remote Sens. 2006, 32, 212-222. [CrossRef]

25. Hyyppä, J.; Hyyppä, H.; Leckie, D.; Gougeon, F.; Yu, X.; Maltamo, M. Review of methods of small-footprint airborne laser scanning for extracting forest inventory data in boreal forests. Int. J. Remote Sens. 2008, 29, 1339-1366. [CrossRef]

26. Baltsavias, E.P. Airborne Laser Scanning: Existing Systems and Firms and Other Resources. J. Photogramm. Remote Sens. 1999, 54, 164-198. [CrossRef]

27. Estornell, J.; Ruiz, L.A.; Velázquez-Martí, B.; Hermosilla, T. Analysis of the factors affecting lidar dtm accuracy in a steep shrub area. Int. J. Digit. Earth 2011, 4, 521-538. [CrossRef]

28. Simpson, J.E.; Smith, T.E.L.; Wooster, M.J. Assessment of errors caused by forest vegetation structure in airborne LiDAR-derived DTMs. Remote Sens. 2017, 9, 1101. [CrossRef]

29. Kirmse, A.; de Ferranti, J. Calculating the prominence and isolation of every mountain in the world. Prog. Phys. Geogr. Earth Environ. 2017, 41, 788-802. [CrossRef]

30. Schwarz, M.; Beul, M.; Droeschel, D.; Schüller, S.; Periyasamy, A.S.; Lenz, C.; Schreiber, M.; Behnke, S. Supervised autonomy for exploration and mobile manipulation in rough terrain with a centaur-like robot. Front. Robot. AI 2016, 3, 57. [CrossRef]

31. Halme, A.; Leppänen, I.; Suomela, J.; Ylönen, S.; Kettunen, I. WorkPartner: Interactive human-like service robot for outdoor applications. Int. J. Rob. Res. 2003, 22, 627-640. [CrossRef]

32. Zielinska, T. Professional and Personal Service Robots. Int. J. Robot. Appl. Technol. 2016, 4, 63-82. [CrossRef]

33. Junyong, C.; Yanping, Z.; Janli, Y.; Chunxi, G.; Peng, Z. Height Determination of Qomolangma Feng (MT. Everest) in 2005. Surv. Rev. 2010, 42, 122-131. [CrossRef]

34. Nishida, T.; Takemura, Y.; Fuchikawa, Y.; Kurogi, S.; Ito, S.; Obata, M.; Hiratsuka, N.; Miyagawa, H.; Watanabe, Y.; Suehiro, T.; et al. Development of a sensor system for outdoor service robot. In Proceedings of the 2006 SICE-ICASE International Joint Conference, Busan, Korea, 18-21 October 2006; Volume 10, pp. 2687-2691. [CrossRef]

35. Raković, M.; Savić, S.; Santos-Victor, J.; Nikolić, M.; Borovac, B. Human-inspired online path planning and biped walking realization in unknown environment. Front. Neurorobot. 2019, 13, 36. [CrossRef]

36. Sutherland, K.T.; Thompson, W.B. Localizing in Unstructured Environments: Dealing with the Errors. IEEE Trans. Robot. Autom. 1994, 10, 740-754. [CrossRef]

37. Samala, N.; Katkam, B.S.; Bellamkonda, R.S.; Rodriguez, R.V. Impact of AI and robotics in the tourism sector: A critical insight. J. Tour. Futur. 2020. [CrossRef]

38. Stankov, U.; Gretzel, U. Tourism 4.0 technologies and tourist experiences: A human-centered design perspective. Inf. Technol. Tour. 2020, 22, 477-488. [CrossRef]

39. Yang, F.; Xue, X.; Cai, C.; Sun, Z.; Zhou, Q. Numerical simulation and analysis on spray drift movement of multirotor plant protection unmanned aerial vehicle. Energies 2018, 11, 2399. [CrossRef]

40. Huang, H.; Savkin, A.V. Path planning for a solar-powered UAV inspecting mountain sites for safety and rescue. Energies 2021, 14, 1968. [CrossRef]

41. Du, Y.C.; Zhang, M.X.; Ling, H.F.; Zheng, Y.J. Evolutionary Planning of Multi-UAV Search for Missing Tourists. IEEE Access 2019, 7, 73480-73492. [CrossRef]

42. Lin, L.; Roscheck, M.; Goodrich, M.A.; Morse, B.S. Supporting Wilderness Search and Rescue with integrated intelligence: Autonomy and information at the right time and the right place. Proc. Natl. Conf. Artif. Intell. 2010, 3, $1542-1547$.

43. Caber, M.; Albayrak, T. Push or pull? Identifying rock climbing tourists' motivations. Tour. Manag. 2016, 55, 74-84. [CrossRef] 
44. Burke, S.M.; Durand-Bush, N.; Doell, K. Exploring feel and motivation with recreational and elite Mount Everest climbers: An ethnographic study. Int. J. Sport Exerc. Psychol. 2010, 8, 373-393. [CrossRef]

45. Apollo, M.; Mostowska, J.; Maciuk, K.; Wengel, Y.; Jones, T.E.; Cheer, J.M. Peak-bagging and cartographic misrepresentations: A call to correction. Curr. Issues Tour. 2021, 24, 1970-1975. [CrossRef]

46. Lew, A.A.; Han, G. A world geography of mountain trekking. In Mountaineering Tourism; Routledge: London, UK, 2015; pp. 19-39. ISBN 9781317668732.

47. Kuby, M.J.; Wentz, E.A.; Vogt, B.J.; Virden, R. Experiences in developing a tourism web site for hiking Arizona's highest summits and deepest canyons. Tour. Geogr. 2001, 3, 454-473. [CrossRef]

48. Crockett, L.J.; Murray, N.P.; Kime, D.B. Self-Determination Strategy in Mountaineering: Collecting Colorado's Highest Peaks. Leis. Sci. 2020, 1-20. [CrossRef]

49. Maciuk, K.; Apollo, M.; Cheer, J.M.; Konečný, O.; Kozioł, K.; Kudrys, J.; Mostowska, J.; Róg, M.; Skorupa, B.; Szombara, S. Determining Peak Altitude on Maps, Books and Cartographic Materials: Multidisciplinary Implications. Remote Sens. 2021, 13, 1111. [CrossRef]

50. European Global Navigation Satellite System Agency. Using GNSS Raw Measurements on Android Devices; White Paper; Publications Office of the European Union: Luxembourg, 2017.

51. Realini, E.; Caldera, S.; Pertusini, L.; Sampietro, D. Precise GNSS positioning using smart devices. Sensors 2017, 17, 2434. [CrossRef] [PubMed]

52. Lachapelle, G.; Gratton, P.; Horrelt, J.; Lemieux, E.; Broumandan, A. Evaluation of a low cost hand held unit with GNSS raw data capability and comparison with an android smartphone. Sensors 2018, 18, 4185. [CrossRef] [PubMed]

53. Natalia, W.; Tomasz, H. Czy to już możliwe? Geodeta 2019, 4, 8-12.

54. Robustelli, U.; Baiocchi, V.; Pugliano, G. Assessment of dual frequency GNSS observations from a Xiaomi Mi 8 android smartphone and positioning performance analysis. Electronics 2019, 8, 91. [CrossRef]

55. Wu, Q.; Sun, M.; Zhou, C.; Zhang, P. Precise Point Positioning Using Dual-Frequency. Sensors 2019, 19, 2189. [CrossRef]

56. Uradziński, M.; Bakuła, M. Assessment of static positioning accuracy using low-cost smartphone GPS devices for geodetic survey points' determination and monitoring. Appl. Sci. 2020, 10, 5308. [CrossRef]

57. Gogoi, N.; Minetto, A.; Linty, N.; Dovis, F. A controlled-environment quality assessment of android GNSS raw measurements. Electronics 2019, 8, 5. [CrossRef]

58. Mouratidis, A.; Ampatzidis, D. European digital elevation model validation against extensive global navigation satellite systems data and comparison with SRTM DEM and ASTER GDEM in Central Macedonia (Greece). Int. J. Geo-Inf. 2019, 8, 108. [CrossRef]

59. Grochala, A.; Nerć, P. Ocena dokładności modelu SRTM 1 dla wybranych obszarów Polski. Przegląd Geodezyjny 2016, 1, 18-22. [CrossRef]

60. Wężyk, P. (Ed.) Podręcznik dla Uczestników Szkoleń z Wykorzystania Produktów LiDAR, 2nd ed.; Główny Urząd Geodezji i Kartografii: Warszawa, Poland, 2015; ISBN 978-83-254-2100-7.

61. Geodesy Cartography and Cadastre Authority of the Slovak Republic Mapový Klient ZBGIS. Available online: https:/ zbgis. skgeodesy.sk/mkzbgis/sk/teren (accessed on 23 January 2021).

62. Geodesy Cartography and Cadastre Authority of the Slovak Republic Projekt-Digitálny Model Reliéfu. Available online: https:/ / www.geoportal.sk/sk/udaje/lls-dmr/o-projekte/ (accessed on 23 January 2021).

63. Geodesy Cartography and Cadastre Authority of the Slovak Republic Parametre pre Lokality Zberu Údajov LLS. Available online: https:/ / www.geoportal.sk/files/zbgis/lls/parametre-lokality-zberu-udajov-lls.pdf (accessed on 23 January 2021).

64. Geodesy Cartography and Cadastre Authority of the Slovak Republic Download. Available online: https://www.geoportal.sk/ en/geodeticke-zaklady/download/ (accessed on 23 January 2021).

65. Head Office of Geodesy and Cartography National Geoportal. Available online: https://mapy.geoportal.gov.pl/imap/Imgp_2. html (accessed on 12 February 2021).

66. Geo++ RINEX Logger. Available online: https:// play.google.com/store/apps/details?id=de.geopp.rinexlogger\&hl=pl (accessed on 2 February 2021).

67. RTKLIB: An Open Source Program Package for GNSS Positioning. Available online: http://www.rtklib.com/ (accessed on 2 February 2021).

68. Rodríguez, E.; Morris, C.S.; Belz, J.E. A global assessment of the SRTM performance. Photogramm. Eng. Remote Sens. 2006, 72, 249-260. [CrossRef]

69. Fahrland, E. Copernicus DEM Product Handbook (v3.0); Airbus Defence and Space GmbH: Taufkirchen, Germany, 2020.

70. Lewandowicz, E. Evaluation of geographical potential of the Warmia and Mazury Province based on the National Register of Geographical Names using geoinformation tools. Ann. Geomat. 2016, XIV, 583-595.

71. ZBGIS. Available online: https://www.geoportal.sk/en/zbgis/ (accessed on 25 February 2021).

72. Stankiewicz, M. Zarys historii produkcji polskich urzędowych map topograficznych. In Rola Bazy Danych Obiektów Topograficznych w Tworzeniu Infrastruktury Informacji Przestrzennej w Polsce; Olszewski, R., Gotlib, D., Eds.; Główny Urząd Geodezji i Kartografii: Warszawa, Poland, 2013; pp. 26-33. ISBN 978-83-254-1975-2.

73. Jakubík, J. Vývoj vojenskej kartografie na území slovenska. Kartografické Listy 2012, 20, $28-38$.

74. Zeman, M. Staré mapové diela na slovensku a ich publikovanie na internete. Kartografické Listy 2012, 20 , 55-61.

75. Malarz, R. Encyklopedia Karpat Polskich; Wydawnictwo Attyka: Kraków, Poland, 2020; ISBN 978-83-65644-73-2. 
76. Kluszczyński, R. Góry Polski-Przezodnik; Kluszczyński: Kraków, Poland, 2006; ISBN 83-7447-041-0.

77. Sikorska, K.; Mikułowski, B.; Werner, Z. Karpaty: Mapa Wakacyjna 1:250,000; Polskie Przedsiębiorstwo Wydawnictw Kartograficznych im. Eugeniusza Romera (PPWK): Warszawa-Wrocław, Poland, 1998.

78. Ostafin, K.; Kaim, D.; Troll, M.; Maciejowski, W. The authorship of the Second Military Survey of Galicia and Austrian Silesia at the scale 1:28,800 and the consistency of sheet content based on selected examples. Pol. Cartogr. Rev. 2020, 52, 141-151. [CrossRef]

79. Timár, G. System of the 1:28 800 scale sheets of the Second Military Survey in Tyrol and Salzburg. Acta Geod. Geophys. Hung. 2009, 44, 95-104. [CrossRef]

80. Křovák, J. Geodetické základy polohopisné a jednotný zobrazovací způsob Československé republiky. Zeměměřický Věstník 1938, 4, 54-58.

81. Marek, J. Mapovanie-Historický Prehl'ad; Slovenská Spoločnost' Geodetov a Kartografov: Bratislava, Slovakia, 2007; ISBN 978-80-969692-1-0.

82. Kuna, J. 'Partially compiled' maps 1:25,000 by Polish Military Geographical Institute (1919-1939). Pol. Cartogr. Rev. 2018, 50, 31-46. [CrossRef]

83. Lewandowski, W.; Więckowski, M. Korona Gór Polski. Poznaj Swój Kraj 1997, XL, 17.

84. Zarząd_Główny_PTTK; Kmisja_Turystyki_Górskiej_PTTK; Komisja_Turystyki_Narciarskiej. Górska Odznaka Turystyczna PTTK, Odznaki Narciarskie PTTK; Centralny Ośrodek Turystyki Górskiej PTTK: Kraków, Poland, 2015; ISBN 978-83-62473-59-5.

85. Solon, J.; Borzyszkowski, J.; Bidłasik, M.; Richling, A.; Badora, K.; Balon, J.; Brzezińska-Wójcik, T.; Chabudziński, Ł.; Dobrowolski, R.; Grzegorczyk, I.; et al. Physico-geographical mesoregions of poland: Verification and adjustment of boundaries on the basis of contemporary spatial data. Geogr. Pol. 2018, 91, 143-170. [CrossRef]

86. Bónová, K.; Bóna, J.; Pańczyk, M.; Kováčik, M.; Mikuš, T.; Laurinc, D. Origin of deep-sea clastics of the Magura Basin (Eocene Makovica sandstones in the Outer Western Carpathians) with constraints of framework petrography, heavy mineral analysis and zircon geochronology. Palaeogeogr. Palaeoclimat. Palaeoecol. 2019, 514, 768-784. [CrossRef]

87. Pánek, T.; Minár, J.; Vitovič, L.; Břežný, M. Post-LGM faulting in Central Europe: LiDAR detection of the $>50$ km-long Sub-Tatra fault, Western Carpathians. Geomorphology 2020, 364, 107248. [CrossRef]

88. Kozak, J. Forest Cover Changes and Their Drivers in the Polish Carpathian Mountains Since 1800. In Reforesting Landscapes; Nagendra, H., Southworth, J., Eds.; Springer: Dordrecht, The Netherlands, 2009; pp. 253-273.

89. Siwicki, M. Nowe Ustalenia Dotyczące Wysokości Szczytów w Tatrach. Available online: https://geoforum.pl/news/29549/ nowe-ustalenia-dotyczace-wysokosci-szczytow-w-tatrach (accessed on 2 September 2020).

90. Pelc-Mieczkowska, R. Preliminary Analysis of the Applicability of the GPS PPP Method in Geodynamic Studies. Geomat. Environ. Eng. 2020, 14, 57-68. [CrossRef]

91. Scalco, P.A.P.; Iescheck, A.L.; Corrêa, I.C.S.; Scottá, F.C.; de Oliveira, R.M.; Franchini, R.A.L. Validation of the Digital Elevation Model (SRTM) with GNSS Surveying Applied to the Mirim Lagoon Hydrographic Basin. Bol. Ciências Geodésicas 2018, 24, 407-425. [CrossRef] 